\title{
O STREAMING SOB UM OLHAR HERMENÊUTICO DO DIREITO DE
} AUTOR

\author{
THE STREAMING UNDER A HERMENEUTICAL VIEW OF COPYRIGHT \\ EL STREAMING BAJO UNA MIRADA HERMENÉUTICA DEL DERECHO DE \\ AUTOR
}

\author{
LARA SANTOS ZANGEROLAME TAROCO \\ http://orcid.org/0000-0002-7532-040X / http://lattes.cnpq.br/5532900244875374 / larasantosz@hotmail.com \\ Universidade do Vale do Rio dos Sinos (UNISINOS) \\ São Leopoldo, RS, Brasil
}

\author{
VICTOR GAMEIRo DRUMMOND \\ https://orcid.org/0000-0003-4147-8783 / http://lattes.cnpq.br/4862618570634510 / victor@victordrummond.com \\ Centro Universitário FG (UNIFG) \\ Guanambi, BA, Brasil
}

\begin{abstract}
RESUMO
O objetivo do presente estudo é analisar o processo conhecido por streaming e as suas consequências no direito de autor contemporâneo, bem como as interpretações quanto à sua natureza jurídica e posição ocupada no ambiente do direito de autor. O streaming se apresenta como a manifestação de uma nova exploração comercial de obras de natureza musical e audiovisual. A possibilidade de múltiplos acessos às obras traz, à contemporaneidade, uma repetição da discussão clássica do direito de autor no que se refere à possibilidade de se auferir lucros e o simples uso de obras ou interpretações protegidas por lei. Considerando os desafios impostos pelas novas tecnologias, a insurgência de conflitos e divergências conceituais em relação ao streaming e o largo histórico de desenvolvimento do direito de autor, é necessário investigar, a partir de um viés hermenêutico, como essa questão tem sido tratada no Brasil, bem como quais são limites e possibilidades hermenêuticas para a adequação do streaming aos pressupostos da legislação vigente.
\end{abstract}

Palavras-chave: Direito de autor; filosofia do direito de autor; streaming.

\section{ABSTRACT}

This article aims to analyze the process known by streaming and its consequences to the contemporary copyright, and its legal nature and position in the copyright field. Streaming is a manifestation of a new commercial exploitation of works of musical and audiovisual nature. With the possibility of multiple accesses to the works brings to contemporary times a repetition of the classic discussion of copyright with regard to the possibility of profit and the simple use of works or interpretations protected by law. Considering the challenges imposed by new technologies, an insurgency of conflicts and conceptual divergences in relation to the transmission and the development history of copyright, it is necessary to investigate, under a hermeneutical view, how this issue has been handled as what are the limits and the hermeneutical possibilities for adapting streaming to the assumptions of current brazilian legislation.

Keywords: Copyright; philosophy of copyright; streaming.

\section{RESUMEN}

Este artículo tiene como objetivo analizar el proceso conocido por transmisión y sus consecuencias para los derechos de autor contemporáneos, y su naturaleza legal y posición en el campo de los derechos de autor. El streaming es una manifestación de una nueva explotación comercial de obras de carácter musical y audiovisual. La posibilidad de múltiples accesos a las obras trae a los tiempos contemporáneos una repetición de la discusión clásica de los derechos de autor con respecto a la posibilidad de obtener ganancias y el simple uso de obras o interpretaciones protegidas por la ley. Teniendo en cuenta los desafíos impuestos por las nuevas tecnologías, una insurgencia de conflictos y divergencias conceptuales en relación con la transmisión y el historial de desarrollo del derecho de autor, es necesario 
ISSN 1981-3694

(DOI): $10.5902 / 1981369453336$

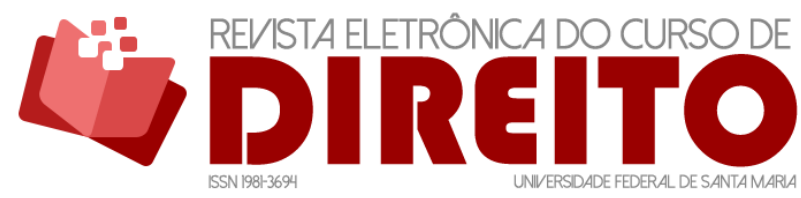

O STREAMING SOB UM OLHAR HERMENÊUTICO DO DIREITO DE

AUTOR

LARA SANTOS ZANGerolame TAROCO VICTOR GAMEIRO DRUMMOND

investigar, bajo una visión hermenéutica, cómo se ha manejado este problema, cuáles son los límites y las limitaciones. Las posibilidades hermenéuticas para adaptar la transmisión a los supuestos de la legislación brasileña actual.

Palabras clave: Derechos de autor; filosofía del derecho de autor; transmisión.

\section{SUMÁRIO}

INTRODUÇAO; 1 DO ENTENDIMENTO DO STREAMING COMO ATO DE TRANSMISSÃO; 2 DOS ATOS DE EXPLORAÇÃO DE OBRAS E INTERPRETAÇÕES; 3 DA LÓGICA SISTÊMICA DE REMUNERAÇÃO DOS AGENTES PARTICIPANTES; 4 DAS MODALIDADES DE STREAMING E OS DIREITOS APLICÁVEIS: BREVE ANÁLISE DA LEGISLAÇÃO E JURISPRUDÊNCIA BRASILEIRAS; 5 A COMPREENSÃO DO ATO DE STREAMING À LUZ DA HERMENÊUTICACONTEMPORÂNEA;

\section{INTRODUÇÃO}

Segundo dados coletados pela Ampere Analysis, consultoria de análise de mídia, conteúdo e comunicação, a América Latina segue em tendência para encerrar o ano de 2020 com 62,2 milhões de clientes de serviços de streaming, em especial de vídeo. Trata-se de um crescimento de $36 \%$ em relação ao número do ano anterior. Ao mesmo tempo, a TV por assinatura via cabo ou satélite tende a permanecer na faixa atual de 57 milhões de clientes.

0 que o levantamento aponta é que nos próximos anos este número deve se estabilizar, contando com eventuais quedas, mas sem previsão de crescimento. Por outro lado, as plataformas de streaming seguem caminho oposto e, segundo a Ampere Analysis, até 2024, serão 110,7 milhões de usuários na América Latina. A expansão e a diversificação das plataformas que disponibilizam esses conteúdos têm relação direta com esse aumento, mas não restam dúvidas que eventos como a pandemia do Covid-19 também irão afetar de forma significativa esse setor. 0 isolamento social imposto por essa emergência de saúde pública interrompeu uma série de atividades ligadas ao audiovisual, mas por outro lado impactou positivamente o streaming.

O direito de autor é uma das categorias jurídicas que mais diretamente sofre os impactos das "novas" tecnologias advindas desde meados da década de 90 do século passado. $\mathrm{E}$ essa nova modalidade de exploração comercial de obras de natureza audiovisual e a possibilidade de múltiplos acessos às obras de certa forma renova à uma clássica questão no âmbito do direito de autor, que se refere à possibilidade de se auferir lucros e o simples uso de obras ou interpretações protegidas por lei

A inadequação de conceitos típicos do mundo analógico ao universo digital é um dos fatores que apresentam dificuldades de diversas ordens, sejam pragmáticas ou teóricas, e que 
ISSN 1981-3694

(DOI): $10.5902 / 1981369453336$

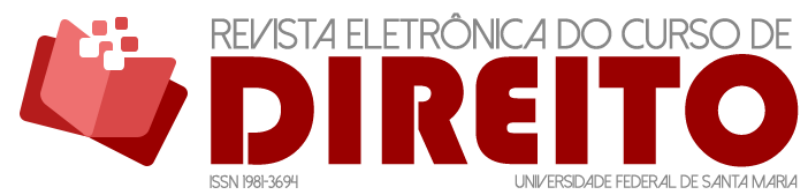

O STREAMING SOB UM OLHAR HERMENÊUTICO DO DIREITO DE

AUTOR

LARA SANTOS ZANGerolame TAROCO VICTOR GAMEIRO DRUMMOND

decorrem, em grande parte, de consequências da incompreensão hermenêutica. Considerando esse cenário o presente estudo pretende apresentar alguma luz ao conceito de streaming com vias a trazer elementos que auxiliem na interpretação do seu entorno para conduzir a soluções jurídicas que tais dificuldades apresentam.

Parte das dificuldades decorre do anacronismo legal e parte de dificuldades cujas respostas podem estar num olhar filosófico no direito de autor, tanto por isso este estudo parte das contribuições da hermenêutica filosófica para analisar streaming como ato de transmissão, e também o direito de comunicação ao público, o direito de reprodução, o direito de distribuição, o direito de colocação a disposição do público, entre outros conceitos, os quais foram manejados em diferentes medidas por este estudo. Isso se faz considerando a legislação brasileira e o estudo comparado de previsões feitas por países como a México, Espanha e Portugal.

Seguindo esse escopo, os atos de exploração de obras e interpretações e a lógica sistêmica de remuneração dos agentes participantes também são analisadas, para em momento seguinte explorar as modalidades de streaming e os direitos aplicáveis. É esse panorama que fornece as condições mínimas para enfrentar a problemática que perpassa este estudo. Isto é, a compreensão do ato de streaming para além de abordagens nominalistas e adequacionistas (dedutivistas), que pretendem estabelecer um suposto marco zero de sentido no âmbito do direito de autor, mas considerando suas implicações para o sujeito-criador, desde já sempre inserido na facticidade e historicidade propugnada pela hermenêutica filosófica.

\section{DO ENTENDIMENTO DO STREAMING COMO ATO DE TRANSMISSÃO}

O streaming é expressão inglesa que significa genericamente transmissão. No caso do universo comunicativo das novas tecnologias, e consequentemente do direito de autor, acabou recebendo um significado de transmissão, mas também o significado de fluxo de mídia (ou fluxo de informação) ${ }^{1}$. Compõe o que Evens e Donders identificam como ampla plataforma, descrevendo o surgimento de uma crescente "infraestrutura e/ou modelo econômico no qual a internet funciona como uma infraestrutura de distribuição mundial para conteúdo audiovisual"2.

\footnotetext{
${ }^{1}$ HAMPTON-SOSA, William. The Access Model for Music and the Effect of Modification, Trial, and Sharing Usage Rights on Streaming Adoption and Piracy. Journal of Theoretical and Applied Electronic Commerce Research. Talca, v.14, n.3, set, 2019. Disponível em: https://www.mdpi.com/07181876/14/3/25. Acesso em: 10 jun. 2021.

2 EVENS, T.; DONDERS, K. Platform Power and Policy in Transforming Television Markets. Cham: Palgrave Macmillan, 2018. p.4. Disponível https://www.degruyter.com/document/doi/10.1515/commun-2019-2034/html. Acesso em: 10 jun. 2021.
} 
ISSN 1981-3694

(DOI): $10.5902 / 1981369453336$

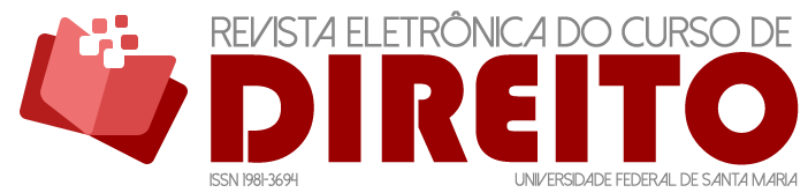

O STREAMING SOB UM OLHAR HERMENÊUTICO DO DIREITO DE

AUTOR

LARA SANTOS ZANGerolame TAROCO VICTOR GAMEIRO DRUMMOND

Ocorre, porém, que o direito de autor, como outras áreas do direito em geral, faz uso de expressões que possuem significado diferente no vocabulário ordinário quando comparado com o vocabulário técnico. 0 fato é que o conceito de transmissão anteriormente definido nas leis nacionais de direito de autor não pode ser completamente avocado, e, neste sentido, a questão começa a se colocar, ainda que também na ordem do pragmatismo da aplicação jurídica, mas primordialmente, como uma questão hermenêutica, nosso principal enfoque.

Neste sentido, é relevante antecipar que é reconhecido o fato de que a doutrina, a jurisprudência e os textos legislativos têm entendido que o ato de transmissão de dados e obras por meio do fluxo destes pode se caracterizar ou não como um (ou uma soma de) direito(s) já previamente existente(s) e, portanto, pela (adequada ou não) aplicação de conceitos prévios. Dito de outra forma, não somente o conceito de transmissão é entendido como necessário para a compreensão do ato de streaming e das relações decorrentes dele.

Além da transmissão, também relevam, entre outros, o direito de comunicação ao público, o direito de reprodução, o direito de distribuição, o direito de colocação a disposição do público ${ }^{3}$, entre outros conceitos, que serão, com maior ou menor brevidade serão estudados neste estudo. O conceito de transmissão é, portanto, bastante amplo e diretamente relacionado a aspectos tecnológicos, ou seja, possui relação direta com o ato de transferência de dados e/ou informações ${ }^{4}$.

No caso do direito de autor, não se vai atribuir definições pela indicação de meras transmissões de dados ou informações, mas, na verdade, elementos mais complexos como sons ou sons e imagens (no caso da lei brasileira) ${ }^{5}$ e obras (no caso das leis espanhola e mexicana) ${ }^{6}$, como se passará a analisar a seguir. Há, portanto, dois significados distintos: um, primeiro, de mera transferência (de dados e, portanto, fluxo de dados e/ou informações e que vem sendo observado como um procedimento técnico extra direito de autor. E um segundo significado, com maior ou menor variação semântica, mas que se refere à transmissão de obras e/ou

\footnotetext{
${ }^{3}$ HAMPTON-SOSA, William. The Access Model for Music and the Effect of Modification, Trial, and Sharing Usage Rights on Streaming Adoption and Piracy. Journal of Theoretical and Applied Electronic Commerce Research. Talca, v.14, n.3, set, 2019. Disponível em: https://www.mdpi.com/07181876/14/3/25. Acesso em: 10 jun. 2021.

${ }^{4}$ HUTCHINS, Brett; LI, Bo. ROWE, David. Over-the-top sport: live streaming services, changing coverage rights markets and the growth of media sport portals. Media, Culture \& Society, v.41, n.7, 2019. Disponível em: https://journals.sagepub.com/doi/pdf/10.1177/0163443719857623. Acesso em: 11 jun. 2021.

${ }^{5}$ BRASIL. Lei $n^{\circ}$ 9.610, de 19 de fevereiro de 1998. Altera, atualiza e consolida a legislação sobre direitos autorais e dá outras providências. Presidência da República. Disponível em: http://www.planalto.gov.br/ccivil_03/leis//9610.htm. Acesso em: 20 jun. 2020.

6 ESPANHA. TRLPI - Real Decreto Legislativo de 01/1996. Disponível em: https://noticias.juridicas.com/base_datos/Anterior/r16-rdleg1-1996.html. Acesso em: 20 jun. 2020.
} 
ISSN 1981-3694

(DOI): $10.5902 / 1981369453336$

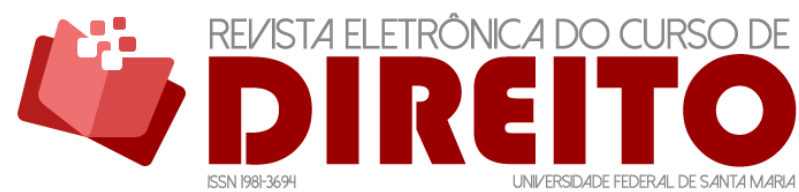

O STREAMING SOB UM OLHAR HERMENÊUTICO DO DIREITO DE

AUTOR

LARA SANTOS ZANGEROLAME TAROCO VICTOR GAMEIRO DRUMMOND

interpretações e que vem sendo utilizado pelas leias nacionais e já, portanto, aproximando-se a definições de atos de exploração aos quais se atribuirão direitos.

Seja no que se refere a meras transferências de dados e informações ou obras, o conceito de transmissão está relacionado, pois, com a ideia de transferência, de menos a mais. A Lei de Direitos Autorais ${ }^{7}$ - n. 9.610/1998 -, por exemplo, define o conceito de transmissão em conjunto com a expressão emissão, tratando-os por sinônimos:

Art. $5^{\circ}$ Para os efeitos desta Lei, considera-se: (...) II - transmissão ou emissão - a difusão de sons ou de sons e imagens, por meio de ondas radioelétricas; sinais de satélite; fio, cabo ou outro condutor; meios óticos ou qualquer outro processo eletromagnético ${ }^{8}$

Outras leis, por sua vez, não estabelecem definições do ato como a lei brasileira, mas incluem a transmissão como uma modalidade técnica e, em algum sentido, espécie do gênero comunicação ao público (o que é bastante questionável do ponto de vista das definições do direito de autor) como é o caso da lei espanhola:

Artículo 20 - Comunicación pública.

1. Se entenderá por comunicación pública todo acto por el cual una pluralidad de personas pueda tener acceso a la obra sin previa distribución de ejemplares a cada una de ellas.

No se considerará pública la comunicación cuando se celebre dentro de un ámbito estrictamente doméstico que no esté integrado o conectado a una red de difusión de cualquier tipo.

2. Especialmente, son actos de comunicación pública: (...)

e) La transmisión de cualesquiera obras al público por hilo, cable, fibra óptica u otro procedimiento análogo, sea o no mediante abono?

A lei mexicana, por sua vez, também não vai definir o ato de transmissão ou a circunstância técnica de transmissão (como faz a brasileira ${ }^{10}$ ) mas vai indicar que a transmissão pública ou radiodifusão de obras (e, portanto, não trata de meros dados ou informações) são

\footnotetext{
${ }^{7}$ BRASIL. Lei $n^{\circ}$ 9.610, de 19 de fevereiro de 1998. Altera, atualiza e consolida a legislação sobre direitos autorais e dá outras providências. Presidência da República. Disponível em: http://www.planalto.gov.br/ccivil_03/leis/[9610.htm. Acesso em: 20 jun. 2020.

8 BRASIL. Constituição da República Federativa do Brasil de 1988. Presidência da República. Disponível em: http://www.planalto.gov.br/constituiao1988. Acesso em: 20 jun. 2020.

9 ESPANHA. TRLPI - Real Decreto Legislativo de 01/1996. Disponível em: https://noticias.juridicas.com/base_datos/Anterior/r16-rdleg1-1996.html. Acesso em: 20 jun. 2020.

${ }^{10}$ A difusão por ondas (radioelétricas); sinais (de satélite); por fio, cabo ou outro condutor; meios óticos ou qualquer outro processo eletromagnético. BRASIL. Lei $\mathrm{n}^{\circ}$ 9.610, de 19 de fevereiro de 1998. Altera, atualiza e consolida a legislação sobre direitos autorais e dá outras providências. Presidência da República. Disponível em: http://www.planalto.gov.br/ccivil_03/leis/19610.htm. Acesso em: 20 jun. 2020.
} 
ISSN 1981-3694

(DOI): $10.5902 / 1981369453336$

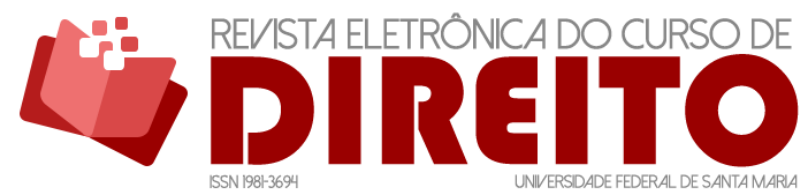

O STREAMING SOB UM OLHAR HERMENÊUTICO DO DIREITO DE

AUTOR

LARA SANTOS ZANGEROLAME TAROCO VICTOR GAMEIRO DRUMMOND

direitos exclusivos atribuíveis aos titulares de direito e dentre as modalidades de transmissão e radiodifusão (como faz a lei espanhola ao indicar que se trata de um dos direitos de exploração), indica modalidades técnicas nas quais estas ocorrem:

Artículo 27.- Los titulares de los derechos patrimoniales podrán autorizar o prohibir: III. La transmisión pública o radiodifusión de sus obras, en cualquier modalidad, incluyendo la transmisión o retransmisión de las obras por: a) Cable; b) Fibra óptica; c) Microondas; d) Vía satélite, o e) Cualquier otro medio conocido o por conocerse ${ }^{11}$.

Em suma, seja com definiç̧ões sobre do que se trata o ato de transmissão (lei brasileira) sobre a indicação de que se trata de direitos de exploração ou espécies de ato de comunicação ao público ou direitos exclusivos (lei espanhola e lei mexicana), o certo é que tais definições não tratam de meras indicações de transferências de dados ou informações, sendo certo que este conceito não poderia ser então definido como a definição de streaming para os efeitos do direito de autor.

O streaming, portanto, ainda que possa ser reconhecido como mero ato técnico de transferência de dados ${ }^{12}$ e/ou informações (e, de fato, genericamente, obras e interpretações podem ser reconhecidas como informações) não está amparado especificamente como modalidade de ato de exploração de obras e/ou interpretações protegidas de forma expressa com esta nomeação, ao menos nos textos legais indicados neste estudo. Daí resulta a necessidade de interpretação das leis para compreender diante de qual ou quais direitos se está diante o se observar o streaming.

Ainda, o conceito de transmissão é, portanto, bastante amplo e diretamente relacionado a aspectos tecnológicos, ou seja, possui relação direta com o ato de transferência de dados (ou pessoas e coisas, mas obviamente aqui se trata de dados e derivações). No caso do direito de autor o conceito de dados acaba por poder ser ampliado, podendo ser sons ou sons e imagens (no caso da lei brasileira) e obras (no caso das leis espanhola e mexicana), conforme quadros abaixo:

\footnotetext{
${ }^{11}$ MÉXICO. Ley Federal del Derecho de Autor. Nueva Ley publicada en el Diario Oficial de la Federación el 24 de diciembre de 1996.2 Disponível em: http://www.diputados.gob.mx/LeyesBiblio/pdf/122_010720.pdf. Acesso em: 10 jun. 2021.

12 Fluxo constante de dados. Na verdade, o stream pode significar um fluxo constante de coisas ou pessoas, mas obviamente que já internamente ao sistema de direito de autor já recebe esta primeira acepção lógica. HUTCHINS, Brett; LI, Bo. ROWE, David. Over-the-top sport: live streaming services, changing coverage rights markets and the growth of media sport portals. Media, Culture \& Society, v.41, n.7, 2019. Disponível em: https://journals.sagepub.com/doi/pdf/10.1177/0163443719857623. Acesso em: 11 jun. 2021.
} 
Quadro 1.

\begin{tabular}{|c|c|c|}
\hline Brasil & Lei $9610 / 98^{13}$ & Art. $5^{\circ}$, inciso II. \\
\hline \multicolumn{3}{|c|}{ Transmissão } \\
\hline Ato & Conteúdo & Forma tecnológica \\
\hline \multirow[t]{7}{*}{ Difusão } & de sons (ou) & (por) ondas rádioelétricas \\
\hline & de imagens (ou) & (por) sinais de satélite \\
\hline & de sons e imagens (ou) & (por) fio \\
\hline & & (por) cabo \\
\hline & & (por) outro condutor \\
\hline & & (por) meios óticos \\
\hline & & (por) outro processo eletromagnético \\
\hline
\end{tabular}

Fonte: Taroco e Drummond (2021)

Quadro 2.

\begin{tabular}{ccc}
\hline Espanha & $\begin{array}{c}\text { TRLPI (Real decreto } \\
\text { legislativo 1/1996) }\end{array}$ & Art. 20, inciso II. \\
\hline & Transmissão (definida como ato de comunicação pública) \\
\hline Ato & Conteúdo & \multicolumn{1}{c}{ Forma tecnológica } \\
\hline Transmissão & de obras & (por) fio ou \\
& & (por) cabo ou \\
& & (por) fibra ótica ou \\
& & (por) outro procedimento análogo \\
\hline
\end{tabular}

Fonte: Taroco e Drummond (2021)

Quadro 3.

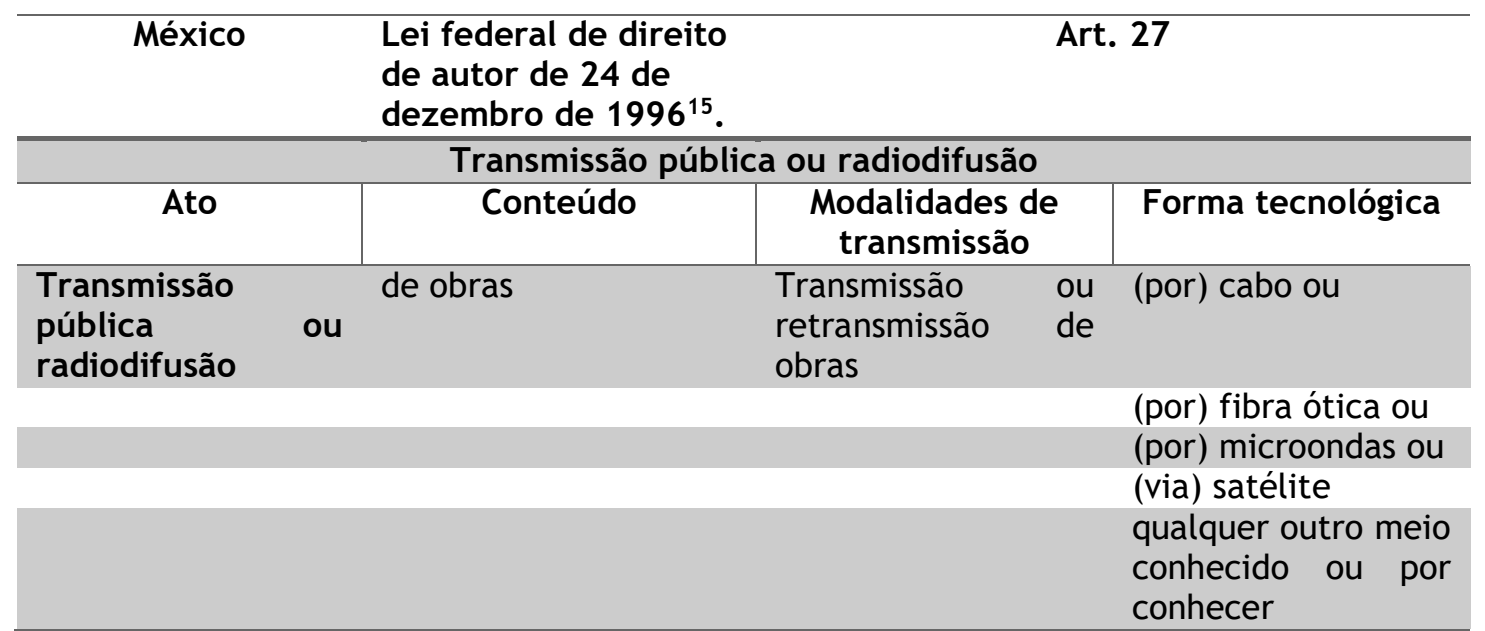

Fonte: Taroco e Drummond (2021)

\footnotetext{
${ }^{13}$ BRASIL. Lei $n^{\circ}$ 9.610, de 19 de fevereiro de 1998. Altera, atualiza e consolida a legislação sobre direitos autorais e dá outras providências. Presidência da República. Disponível em: http://www.planalto.gov.br/ccivil_03/leis/l9610.htm. Acesso em: 20 jun. 2020

14 ESPANHA. TRLPI - Real Decreto Legislativo de 01/1996. Disponível em: http://noticias.juridicas.com/base_datos/Admin/rdleg1-1996.htm. Acesso em: 20 jun. 2020.

${ }_{15}$ MÉXICO. Ley Federal del Derecho de Autor. Nueva Ley publicada en el Diario Oficial de la Federación el 24 de diciembre de 1996. Disponível em:

http://www.diputados.gob.mx/LeyesBiblio/pdf/122_010720.pdf. Acesso em: 10 jun. 2021.
} 
ISSN 1981-3694

(DOI): $10.5902 / 1981369453336$

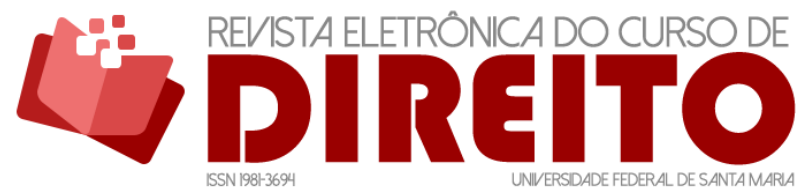

O STREAMING SOB UM OLHAR HERMENÊUTICO DO DIREITO DE

AUTOR

Há, portanto, dois significados distintos: um primeiro e realmente mais genérico, e de certa forma amplo, de mera transferência de dados e, portanto, fluxo de dados e/ou informações e que vem sendo observado como um procedimento técnico extra direito de autor. E um segundo significado, com maior ou menor variação semântica, mas que se refere à transmissão de obras e/ou interpretações. Sendo uma transmissão meramente de dados, poderia haver evidentes questionamentos no âmbito do direito de autor ${ }^{16}$, sobretudo, ao se analisar quais dados estariam sendo objeto de transferência e, sobretudo, qual a natureza e titularidade dos bancos de dados que poderiam ser (em conjunto ou isoladamente).

Não obstante tal fato, é mais relevante para este estudo a análise efetiva dos objetos de direito de autor protegidos sob a forma de obras e interpretações, plasmados em quaisquer de suas concepções técnicas, primordialmente sons e imagens separadamente ou conjuntamente. Desta forma, releva compreender o fato de que os atos de exploração conduzem à aplicabilidade de direitos que lhes sejam ínsitos e esta análise é a que será responsável por compreender o espaço no sistema de direito de autor, que o streaming ocupa.

\section{DOS DIFERENTES ATOS DE EXPLORAÇÃO DE OBRAS E INTERPRETAÇÕES}

Vistas as definições possíveis ao ato de streaming como ato de transmissão, cabe compreender a circunstância tecnológica que conduz ao ato de transmissão para que daí se possa partir para a extração de um conceito jurídico. Analisando-se o conceito jurídico, seguidamente deve-se compreender de que forma o direito se coloca. Dito de outra forma, trata-se, antes de tudo, de se identificar a existência de um direito que seja aplicável à circunstância técnica.

No caso do direito de autor, a aplicação e a existência ou não de um direito decorrem da análise do uso de obras relacionadas às possibilidades que a tecnologia possibilita. 0 direito de autor e os direitos conexos ${ }^{17}$ devem ser aplicados sempre que houver uma distribuição das obras para um maior público.

16 HORNER, Stephanie N. DMCA: Professional Sports Leagues' Answer to Protecting Their Broadcasting Rights against Illegal Streaming. Marquette Sports Law Review, v.24, n.6, 2014. Disponível em: https: / / heinonline.org/HOL/LandingPage?handle=hein.journals/mqslr24\&div=19\&id=\&page=. Acesso em: 13 jun. 2021.

17 DRUMMOND, Victor. $O$ ator e o não-direito do criador inominado. In: MOREIRA, Nelson Camatta; DE PAULA, Rodrigo Francisco de. Direito e literatura distópica. São Paulo: Tirant Lo Blanch, 2020. 
ISSN 1981-3694

(DOI): $10.5902 / 1981369453336$

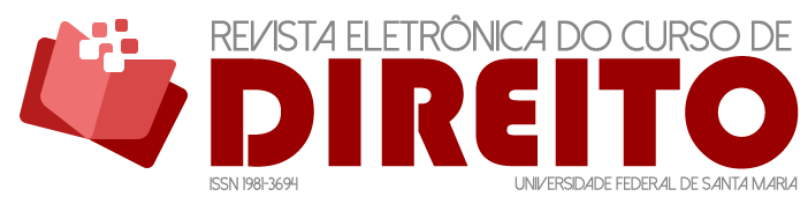

O STREAMING SOB UM OLHAR HERMENÊUTICO DO DIREITO DE

AUTOR

LARA SANTOS ZANGerolame TAROCO VICTOR GAMEIRO DRUMMOND

Distribuição aqui, recebe, na verdade, o significado de ato genérico que faz chegar à obra ou a interpretação ao alcance do público a que interessa o autor ou intérprete. Fazemos a ressalva pois não se trata do uso da expressão distribuição no conceito legalmente definido na legislação de direito de autor ${ }^{18}$, mas do uso genérico de fazer chegar a terceiros que não o sujeito-criador ou o titular.

A lógica do direito de autor contempla que obras que serão, em maior ou menor medida, transformadas em produtos ou serviços, e que possam gerar mais lucros aos agentes participantes da cadeia distributiva ${ }^{19}$, devem gerar lucros para todos os envolvidos nesta cadeia genericamente considerada distributiva (que poderia também ser definida como cadeia produtiva).

Ou seja, em suma, toda a lógica do direito de autor que se pretenda justa e equilibrada deveria se basear no fato de que: para cada ato que gere um uso de uma obra ou interpretação (ou produto que seja derivado de uma ou várias destas), deve-se acoplar um direito, considerando o fato de que o fato gerador é o uso da obra ou interpretação ${ }^{20}$. É deste ponto que se parte para a compreensão do direito de autor. Há limites e exceções - que justificam a inaplicabilidade eventual do direito de autor - mas a lógica genérica (sistêmica) deve ser considerada.

Toda e qualquer variação de direito é, portanto, uma atribuição pela possibilidade de as obras chegarem a um maior número de pessoas, o que faz com que sejam, portanto, todos os direitos inerentes, espécies de "sucessores" do direito de reprodução. Isso ocorre pelo fato de que o desenvolvimento tecnológico que fez surgir o direito de autor foi exatamente aquele que permitiu a reprodução de obras de forma ampla, qual seja, o desenvolvimento dos tipos móveis na civilização ocidental. Ou seja, com o surgimento da imprensa, a única forma tecnológica de aumentar a multiplicidade de acessos às obras era a reprodução. Ou seja, o surgimento do

18 Tomando por exemplo a definição da lei brasileira. BRASIL. Lei $n^{\circ} 9.610$, de 19 de fevereiro de 1998. Altera, atualiza e consolida a legislação sobre direitos autorais e dá outras providências. Presidência da República. Disponível em: http://www.planalto.gov.br/ccivil_03/leis/l9610.htm. Acesso em: 20 jun. 2020. Art. $5^{\circ}$. IV - distribuição - a colocação à disposição do público do original ou cópia de obras literárias, artísticas ou científicas, interpretações ou execuções fixadas e fonogramas, mediante a venda, locação ou qualquer outra forma de transferência de propriedade ou posse.

19 Contemplando-se nesta definição em sentido lato a criação, a produção, a distribuição ou qualquer outro ato cuja participação que possua textos valor econômico possa estar presente. BRASIL. Lei $n^{\circ}$ 9.610, de 19 de fevereiro de 1998. Altera, atualiza e consolida a legislação sobre direitos autorais e dá outras providências. Presidência da República. Disponível http://www.planalto.gov.br/ccivil_03/leis/[9610.htm. Acesso em: 20 jun. 2020.

20 WACHOWICZ, Marcos. O "novo" direito autoral na sociedade informacional. In: WOLKMER, A. C.; LEITE, J. R. N (Org). Os "novos" direitos no Brasil: natureza e perspectivas - uma visão básica das novas conflituosidades jurídicas. 3. ed. São Paulo: Saraiva, 2016. p. 56. 
ISSN 1981-3694

(DOI): $10.5902 / 1981369453336$

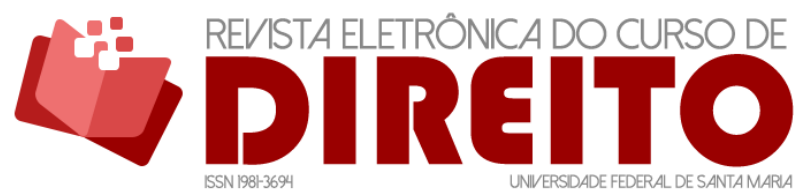

O STREAMING SOB UM OLHAR HERMENÊUTICO DO DIREITO DE

AUTOR

LARA SANTOS ZANGerolame TAROCO VICTOR GAMEIRO DRUMMOND

direito se baseou num feixe de direitos cujo conteúdo era 100\% de um único direito: o direito de permitir ou proibir a reprodução de obras.

Neste sentido, consoante o tipo de obra existente, serão identificados direitos - e serão aplicados - como consequência da natureza das referidas obras (e interpretações) e seus respectivos usos. Assim sendo, uma obra de artes plásticas será exibida (considerando ser a exibição o ato decorrente de sua natureza) enquanto que uma obra musical poderá ser executada. Ambas, por sua vez, poderão ser objeto de reprodução. Assim, deve ser feita a pergunta, claramente tautológica: uma obra musical pode ser utilizada como obra de qual forma? E daí se parte para a compreensão da existência prévia de um direito por assim dizer, acoplável ao uso. Uso este, neste caso, que poderá representar uma exploração comercial de alguma forma.

No caso do presente estudo, o objeto de análise, ou seja, o ato de streaming bem como de toda e qualquer análise de uma nova forma de exploração de obras protegidas por direito de autor e que tradicionalmente não era previsto no sistema recebe críticas do setor autoral. 0 conflito se coloca de forma bastante clara e com evidente cunho comercial. O streaming é, possivelmente, a modalidade de exploração de obras contemporânea do direito de autor que mais discussões traz, justamente por representar o "esgotamento dos limites tracionais na sociedade informacional"21. Não raro, portanto, os agentes dos interesses envolvidos nas disputas de direito de autor põem em prática todo o seu arcabouço teórico para definir a natureza jurídica dos atos de exploração comercial que serão ou não encontrados nas legislações nacionais ou internacionais.

Desta forma, há de observar que se está diante de uma certa inversão à pergunta, quando se pretende perguntar se o streaming é um uso já existente como direito previamente observável nas legislações nacionais de direito de autor. Daí a questão relevante: se é um ato já previsto como direito (faculdade) e se já há uma ambientação legislativa suficiente para indicar o que deve ocorrer como consequência do uso de obras musicais (por exemplo). A resposta sistemicamente é, portanto, positiva. A discussão acaba por basear-se muitas vezes em critérios de ordem econômica e as respostas para o direito de autor devem ser encontradas nas razões filosóficas.

${ }^{21}$ WACHOWICZ, Marcos. O "novo" direito autoral na sociedade informacional. In: WOLKMER, A. C.; LEITE, J. R. N (Org). Os "novos" direitos no Brasil: natureza e perspectivas - uma visão básica das novas conflituosidades jurídicas. 3. ed. São Paulo: Saraiva, 2016. p. 55. 
ISSN 1981-3694

(DOI): $10.5902 / 1981369453336$

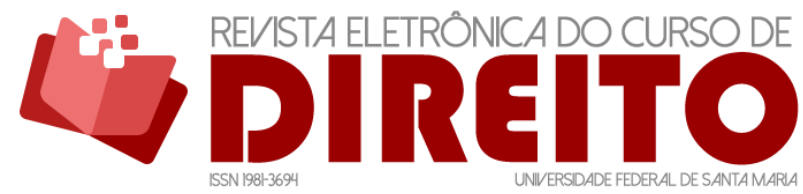

O STREAMING SOB UM OLHAR HERMENÊUTICO DO DIREITO DE

AUTOR

LARA SANTOS ZANGerolame TAROCO VICTOR GAMEIRO DRUMMOND

Ou seja, a pergunta concreta e correta é: será justa e adequada a remuneração, especialmente aos autores e intérpretes das obras musicais ou de audiovisual (e quaisquer outras modalidades submetidas a idêntico tratamento), que sejam vinculadas à nova forma de exploração comercial (ato exploratório) que configura o streaming? A pergunta, sendo assim formulada, conduz à obviedade do seu questionamento: sim, pois cada ato de exploração comercial equivalente a um uso típico de uma determinada modalidade de obra.

Daí que nunca se pode esquecer que a reprodução foi o processo técnico que permitiu a multiplicação de exemplares e, consequentemente, a multiplicidade de acesso às obras por parte do público. Neste sentido, o ato de reprodução e o consequente direito de reprodução é o fundamento existencial empírico primeiro do direito de autor como sistema e, tal lógica, necessita ser compreendida na sua complexidade hermenêutica como sistema jurídico.

\section{DA LÓGICA SISTÊMICA DE REMUNERAÇÃO DOS AGENTES PARTICIPANTES}

É chegado o momento de perceber que o direito de autor se baseia numa lógica econômica que decorre da compreensão de que quanto mais explorações comerciais podem ser aplicadas a uma obra ou interpretação, mais lucros elas poderão gerar àqueles que participaram do processo criativo. Mais do que isso, a variação econômica da multiplicidade de usos (num sentido genérico de distribuição) de produtos e serviços em escala deve atender a uma distribuição minimamente equilibrada entre os sujeitos participantes deste processo.

Assim, tomando por exemplo a exploração comercial de uma obra literária pela via da distribuição de exemplares, há de se levar em conta que ela deverá gerar valores inerentes aos direitos que se aplicam ao autor da obra literária e quantos mais forem os beneficiários na cadeia produtiva e distributiva. No caso de distribuição de obras literárias com exemplares físicos, a editora, a distribuidora, além do autor.

Nesta mesma lógica, considerando-se a distribuição digital, os envolvidos no processo criativo, produtivo e distributivo devem também ser beneficiados. De toda forma, não se pode esquecer que o autor da obra literária deve ser o beneficiário nunca olvidado e sempre considerado como o primordial sujeito de direito de autor. Ocorrendo a produção e a distribuição de obra literária pela via de distribuição de exemplares físicos ou pela via digital, o autor nunca pode deixar de ser beneficiado sob o argumento frágil de que não há previsão contratual para tal remuneração, não obstante ocorrer o lucro do agente econômico que dá cabo à exploração. Este fato decorre de que o direito de autor se manifesta filosoficamente como a 
ISSN 1981-3694

(DOI): $10.5902 / 1981369453336$

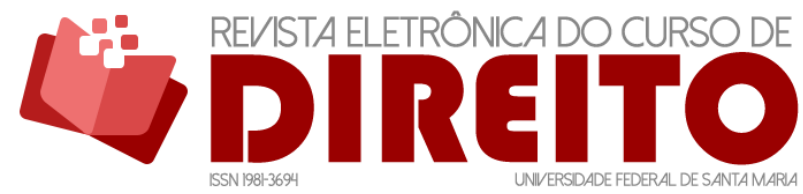

O STREAMING SOB UM OLHAR HERMENÊUTICO DO DIREITO DE

AUTOR

LARA SANTOS ZANGerolame TAROCO VICTOR GAMEIRO DRUMMOND

categoria jurídica que atribui direitos pelo ato da criação no domínio das artes, da cultura e das ciências, e como consequência, aos agentes que fazem com que as obras e interpretações surgidas pela criação deste universo se transformem em produtos.

Esta lógica de aplicação de direito a múltiplas explorações comerciais decorre exatamente do fato de que, quanto mais se pode auferir lucros pelos produtos que são originários de obras criadas ou interpretadas por autores ou intérpretes é o fator economicamente decisivo no direito de autor, desde os seus primórdios como manifestação de direito aplicável pela multiplicação de exemplares ${ }^{22}$.

Dito de outro modo, o direito de autor passa a fazer sentido como tal com a possibilidade de multiplicação de exemplares decorrentes do advento da imprensa e dos investimentos em equipamento e tecnologia. Este investimento, porém, não pode suplantar o ato da criação. Assim, historicamente, mesmo que parte do estimulo legislativo primeiro ocorrido no sistema de copyright $^{23}$ tenha advindo dos detentores dos meios de produção de obras literárias e obras musicais reproduzidas graficamente, não se pode olvidar que este fato foi uma mera consequência jurídica decorrente de fatores como a não compreensão - até aquele momento histórico - do conceito de autor.

Disso decorre o próprio déficit filosófico do direito de autor ${ }^{24}$, enquanto uma equivocada interpretação já manifestada no momento histórico de sua formação, o que comprova a ausência da compreensão de uma justificativa filosófica para a atribuição do direito de autor como categoria jurídica, considerando a condição do sujeito-criador ${ }^{25}$. Isso se perpetua desde seu surgimento fazendo com que não se leve em conta a essência do processo criativo nas análises históricas, e principalmente filosóficas.

A partir dessas premissas, o Direito passa a funcionar como meio para atender aos anseios de natureza econômica, mesmo quando "ocorria uma valorização mais acentuada do

\footnotetext{
22 DRUMMOND, Victor Gameiro. Baena e Dias: pioneiros dos privilégios atribuídos aos autores portugueses no século XVI e suas consequências nas novas tecnologias. Revista Brasileira de Direito. Passo Fundo, v. 13, n.3. p. 423.

${ }^{23}$ Para Rose Mark, tradicionalmente o termo copy era utilizado no ambiente do Stationers com um dentre dois significados: o do manuscrito em si e o do direito de fazer cópias desse (compreendido o manuscrito como a base para as cópias). ROSE, Mark, Authors and Owners. The invention of copyright. Harvard University Press, London: 1993. p. 12. Esta indicação é relevante para comprovar o aspecto do surgimento do direito de autor - seja no copyright, seja no droit d'auteur, já amparado em concepções semânticas em parte desviantes, e alimentando o déficit filosófico do direito de autor.

${ }^{24}$ DRUMMOND, Victor Gameiro. 0 déficit filosófico do direito de autor. Revista Paradigma. Ribeirão Preto. v.26, n.1, jan/jun, 2017. p.168. Disponível em: http://revistas.unaerp.br/paradigma/article/view/847. Acesso em: 06 de mai. 2020.

${ }^{25}$ DRUMMOND, Victor. Do círculo hermenêutico ao círculo criativo, (as novas) perspectivas filosóficas do direito de autor. Tese. Rio de Janeiro: Universidade Estácio de Sá. 2014.
} 
ISSN 1981-3694

(DOI): $10.5902 / 1981369453336$

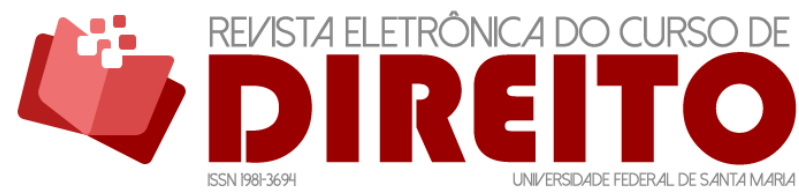

O STREAMING SOB UM OLHAR HERMENÊUTICO DO DIREITO DE

AUTOR

LARA SANTOS ZANGerolame TAROCO VICTOR GAMEIRO DRUMMOND

personalismo, com foi naturalmente o processo de formação do direito de autor de caráter revolucionário francês" ${ }^{26}$. Não se trata de afastar as justificativas econômicas, também relevantes para o desenvolvimento do direito do autor no cenário contemporâneo, mas enquadrar de forma devida à questão, considerando a não promiscuidade entre argumento econômicos e a justificação filosófica do direito de autor.

Diante desta perspectiva é importante compreender que o streaming, como manifestação de nova exploração comercial de obras de natureza musical e possibilidade de múltiplos acessos às obras, traz, à contemporaneidade uma repetição da discussão clássica do direito de autor no que se refere à possibilidade de se auferir lucros e o simples uso de obras ou interpretações protegidas por $\operatorname{lei}^{27}$.

Dito de outra forma, se nos idos dos séculos XVI a XVIII a discussão sobre o direito de autor se baseava na concepção de que havia um investimento e que tal investimento devia ser protegido - fato que obviamente não se nega e está inserido na lógica da possibilidade de se fazer a obra chegar sob a forma de produto ao seu público - também não se pode negar que o principal destinatário do sistema de direito de autor deve ser aquele que dá nome a tal direito.

Porém, que o fato de que se deve compreender que o autor é a figura principal da atribuição de tal categoria jurídica não significa dizer que ele deve ser o principal beneficiário econômico. Isto porque muitas vezes, na transformação de uma obra em produto, os custos que promovem tal transformação pode ser altamente significativos. Ainda assim, porém, nunca se pode afastar a lógica de que o autor deve estar presente na cadeia dos beneficiários.

Atualizando-se a discussão para o caso do streaming, não há nenhuma modificação nesta concepção ideológica e econômica. O que ocorre, porém, é que desvios semânticos e hermenêuticos podem ocorrer na tentativa de se atribuir presença ou ausência de direitos, o que é objeto da análise deste texto. Por exemplo: indica-se que o pagamento por parte de empresas pelo uso das obras cuja utilização se dá sob a forma de streaming já estaria contemplado no direito de reprodução pago às gravadoras.

Ocorre que o uso das obras sob a forma de streaming não se relaciona com a reprodução em si, mas o uso transitório e efêmero do arquivo que pode ser utilizado online, sem nenhuma

${ }^{26}$ DRUMMOND, Victor Gameiro. O déficit filosófico do direito de autor. Revista Paradigma. Ribeirão Preto. v.26, n.1, jan/jun, 2017. p.168. Disponível em: http://revistas.unaerp.br/paradigma/article/view/8. Acesso em: 06 de mai. 2020. p.171.

${ }^{27}$ WACHOWICZ, Marcos. A gestão coletiva de direitos autoraisda obra musical: titularidade originária, supervisão pública e transparência. In: SIMÃO, J.F.; BELTRÃO, S.R. Estudos em Homenagem a José de Oliveira Ascensão - Direito Civil: Estudos Em Homenagem A José De Oliveira Ascensão: Direito Privado. Editora: Atlas, 2015. p.268. 
ISSN 1981-3694

(DOI): $10.5902 / 1981369453336$

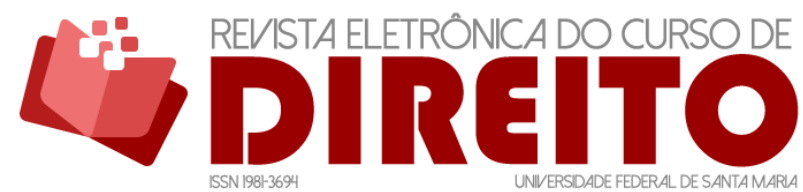

O STREAMING SOB UM OLHAR HERMENÊUTICO DO DIREITO DE

AUTOR

LARA SANTOS ZANGerolame TAROCO VICTOR GAMEIRO DRUMMOND

transferência da obra, mas somente pelo fluxo dos dados (ou seja, levando em conta a primeira das definições de streaming prevista no início deste estudo, qual seja, streaming no sentido de transferência de dados) ${ }^{28}$.

Adiantando, portanto, parte das conclusões, o streaming é modalidade de exploração de obras protegidas pelo sistema de direito de autor e direitos conexos. Tal modalidade de exploração comercial, porém, não se apresenta como modalidade expressamente prevista nas legislações nacionais, como é o caso da legislação brasileira, talvez da forma que os agentes do setor desejem, seja por clareza hermenêutica ou por interesse econômico.

Em linhas gerais, para cada uso de obra ou interpretação reconhecida no mundo fático há de se reconhecer também um direito individual baseado na lógica já indicada de que quanto mais uso se faz de obras ou interpretações, mais devem, os envolvidos na cadeia criativa, produtiva e distributiva ser beneficiados, o que inclui os criadores. Neste sentido, a inexistência da nomeação a um direito, que por sua vez deve ser aplicado à uma circunstância, não inibe a existência do direito aplicável ou mesmo do ato em si. A inexistência do nome de algo não faz com que este algo deixe de existir.

Considerando o giro ontológico-linguístico da hermenêutica filosófica, os conceitos, assim como os métodos interpretativos, chegam tarde diante do fenômeno da pré-compreensão, ao passo que não são fatores determinantes para a preparação e formação de um conhecimento válido ou atribuição de um direito. Existem estruturas que se situam antes de qualquer aporte metodológico ou nominalista, que já constituem, portanto, o conhecimento, pois o acontecer da verdade não está condicionado a um método pré-estabelecido de conhecimento ${ }^{29}$.

A viragem linguística interessa filosoficamente ao direito de autor ${ }^{30}$ na medida em que se trata de um problema de ordem hermenêutica muito antes de se manifestar como uma questão de direito de autor, tanto por isso, que remete à compreensão do direito como um conceito

\footnotetext{
${ }^{28}$ HORNER, Stephanie N. DMCA: Professional Sports Leagues' Answer to Protecting Their Broadcasting Rights against Illegal Streaming. Marquette Sports Law Review, v.24, n.6, 2014. Disponível em: https: //heinonline.org/HOL/LandingPage?handle=hein.journals/mqslr24\&div=19\&id=\&page=. Acesso em: 13 jun. 2021. p.48.

29 STRECK, Lenio Luiz. Dicionário de hermenêutica: quarenta temas fundamentais da Teoria do Direito à luz da Crítica Hermenêutica do Direito. Belo Horizonte: Letramento, 2017. p. 161.

30 DRUMMOND, Victor Gameiro. The creative circle: why the linguistic turn is of philosophical interest in copyright law. Revista de Estudos Constitucionais, Hermenêutica e Teoria do Direito (RECHTD). v.5, n.1, 2013. p.78.
} 
ISSN 1981-3694

(DOI): $10.5902 / 1981369453336$

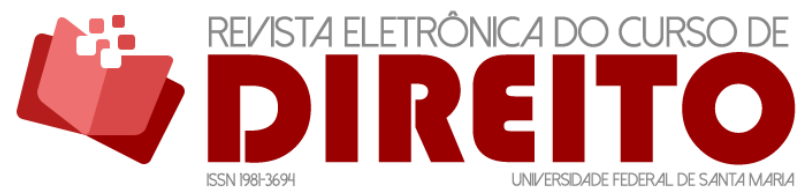

O STREAMING SOB UM OLHAR HERMENÊUTICO DO DIREITO DE

AUTOR

interpretativo, que afasta abordagens nominalistas, para quem há a possibilidade de um grau zero de sentido e inexiste nenhuma realidade exterior ao indivíduo ${ }^{31}$.

Não se trata, porém, de qualquer atribuição de direito natural, sendo certo que este argumento poderia ser utilizado pelos detratores da ideia agora desenvolvida. 0 que gera 0 direito não é uma condição naturalmente esperada, mas a compreensão de que o ato de reprodução significa, antes de tudo, a única modalidade existente, no surgimento do direito de autor (e até mesmo antes) de multiplicação de acesso a obras (antes mesmo de se pensar o conceito de obras protegidas).

A nomeação do ato de exploração da obra é que releva para os efeitos da discussão implementada no estudo. Esconder o direito pelo nome que se pretende acoplar é o que pretendem aqueles que entendem que o streaming não merece guarida como direito autônomo ou mesmo como consideração, no mínimo, de que o rol de direitos existentes seria suficiente para enquadrar o streaming como uma exploração comercial.

$\mathrm{Na}$ verdade, o caminho é compreender se o ato é autônomo e se corresponde às considerações sistêmicas. A resposta é evidente: sim, o streaming é forma de exploração de obra que segue uma razão histórica da multiplicação de acesso a obras. Desvelar o nome pelo conceito é o que deve fazer o hermeneuta e, neste caso, evidencia-se que se trata de um direito cujo nome ainda não havia sido apontado antes das questões econômicas, já que a economia e a tecnologia invadiram o mundo do Direito outra vez mais no caso do streaming, como costuma ocorrer.

Compreendida a urgência hermenêutica, é fundamental compreender as formas existentes de streaming até o momento, para a compreensão dos direitos que lhes seriam aplicáveis.

\section{DAS MODALIDADES DE STREAMING E OS DIREITOS APLICÁVEIS: BREVE ANÁLISE DA LEGISLAÇÃO E JURISPRUDÊNCIA BRASILEIRAS}

A indicação de formas de exploração de obras baseada em conceitos tecnológicos traz um enorme risco científico do ponto de vista da adequabilidade e atualidade dos conceitos. Há

\footnotetext{
31 WACHOWICZ, Marcos. O "novo" direito autoral na sociedade informacional. In: WOLKMER, A. C.; LEITE, J. R. N (Org). Os "novos" direitos no Brasil: natureza e perspectivas - uma visão básica das novas conflituosidades jurídicas. 3. ed. São Paulo: Saraiva, 2016. p.52.
} 
ISSN 1981-3694

(DOI): $10.5902 / 1981369453336$

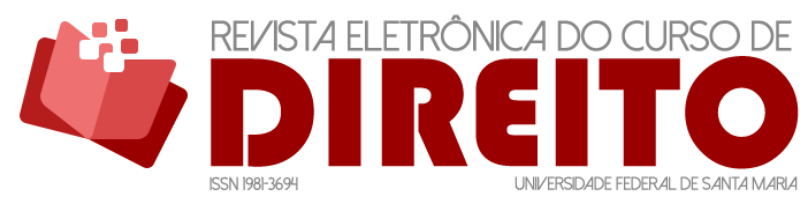

O STREAMING SOB UM OLHAR HERMENÊUTICO DO DIREITO DE

AUTOR

LARA SANTOS ZANGEROLAME TAROCO VICTOR GAMEIRO DRUMMOND

enorme chance de um leitor aceder ao estudo já com a perda de adequabilidade. Não obstante esta circunstância acadêmica, é fundamental compreender as diversas formas existentes de streaming até o momento.

Tal urgência se dá pela obviedade da necessidade da compreensão dos conceitos técnicos para a posterior análise da viabilidade de conceitos jurídicos já reconhecidos pela legislação e pela jurisprudência. 0 streaming surgiu em 2006 e permite o acesso online de pacotes de dados armazenados em nuvem, não sendo necessário possuir memória no computador ou celular, bastando apenas possuir acesso à internet e um login e senha para se ter acesso ${ }^{32}$.

A partir disso, é possível destacar, incialmente, dois desdobramentos do streaming: não interativo e interativo (on demand). Na primeira modalidade a interatividade quase não existe e tanto por isso trata-se de modelo que em muito se aproxima das rádios tradicionais. Isso porque o usuário não tem a faculdade de escolher o que irá ver ou ouvir. Aqui se inclui o simulcasting modalidade na qual se reproduz de forma simultânea um programa via radiodifusão ${ }^{33}$.

A segunda modalidade, qual seja, o streaming interativo ou on demand, pauta-se, como o próprio termo em inglês busca designar, no controle do usuário que pode iniciar a transmissão quando desejar, como se dispusesse do fonograma ou de outro arquivo de obra de outra natureza, como por exemplo é o caso das obras de audiovisual. 0 webcasting on demand se enquadra nessa categoria, assim como as principais plataformas de streaming ${ }^{34}$, que igualmente se ajustam à própria proposta da Internet, também fundada na lógica "sob demanda".

Essa combinação enquadra-se na tendência atual por acesso rápido, disponível e "a qualquer hora e em qualquer lugar" que vêm se intensificando com a maior difusão do acesso à Internet, o que também repercute em uma progressiva substituição das modalidades até então $\operatorname{adotadas}^{35}$. Os usuários passam, então, a poder escolher dentre distintas plataformas que possibilitam o armazenamento em nuvem online ou off-line, com amplos catálogos e diferentes capacidades e formas de organização desse conteúdo.

\footnotetext{
32 KISCHINHEVSKY, Marcelo. Em busca da música infinita: os serviços de streaming e os conflitos de interesse no mercado de conteúdos digitais. São Leopoldo: Unisinos, 2015, p.41.

${ }_{33}$ SAKTHIVEL, Marc. Evolution of the Authors' Right of Communication to Public: Implications to Broadcasters in the Context of Live Streaming. In: SAKTHIVEL, Marc. Broadcasters' Rights in the Digital Era: copyright concerns on live streaming. Leiden: Brill\&Nijhoff, 2020. p.36.

${ }^{34}$ ROSATI, Eleonora. Does the Duration of the Storage Matter? Live Streaming Providers As 'Online Content Sharing Service Providers' Under Directive 2019/790. European Intellectual Property Review, 2020. p.45.

${ }^{35}$ Como aponta a análise feita por Lin, os usuários da Internet que estão mais interessados em adotar a visualização de webcast também têm a tendência de: (1) capitalizar a natureza fluida da Internet, (2) procurar satisfazer suas expectativas de gratificação afetiva, (3) substituir a escuta de rádio por acesso via rádio on-line e (4) permanecer on-line por um período maior a cada visita. LIN, Carolyn A. Technology fluidity and on-demand webcasting adoption. Telematics and Informatics. v. 12, n.2, maio, 2008. p.88.
} 
ISSN 1981-3694

(DOI): $10.5902 / 1981369453336$

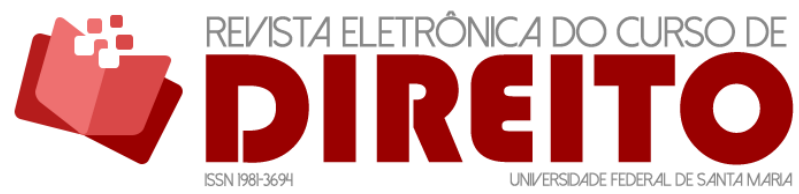

O STREAMING SOB UM OLHAR HERMENÊUTICO DO DIREITO DE

AUTOR

LARA SANTOS ZANGerolame TAROCO VICTOR GAMEIRO DRUMMOND

Compreendidas as terminologias inerentes ao processo de uso de obras pela modalidade de streaming, é chegado o momento da compreensão do entorno de aplicação jurídica dos direitos existentes. Portanto, há de se compreender que o ato de se fazer uso de obras musicais ou de outra natureza por conta de sua natureza digital de forma a usufruir de tais obras (e interpretações) como consequência de novas formas de utilização, deve gerar discussões jurídicas como consequência dos atos que as obras podem sofrer. É, pois o mesmo processo histórico-interpretativo inerente ao surgimento da imprensa, do fonograma e da radiodifusão.

Tomando-se como exemplo o uso sob a forma de sincronização com bancos de dados, por meio de aparatos digitais (notebooks, tablets, smartphones, por exemplo) é obviamente uma forma de exploração de obras e interpretações e o fato de se vislumbrar uma impossibilidade de aplicação específica ou determinante que indique expressamente, por exemplo: o uso próprio, por usuário final, de obra inserida em base de dados, em momento definido por ele com a eventual reprodução do arquivo correspondente deve gerar direitos aos titulares dos direitos envolvidos.

Como se sabe, esta, que poderia uma espécie de definição de streaming on demand, não está prevista na maior parte das leis nacionais. O fato, portanto, de não estar prevista na legislação a disponibilidade de obra para uso de acordo com o interesse do consumidor final não inibe a existência de um ato que, neste caso, se refere a ato comercial e, portanto, para tal ato se aplica um direito.

Há, portanto, sim, casos de aplicabilidade mais aproximada de direitos ao streaming, sobretudo com a evolução dos chamados Tratados da Internet da OMPI (WCT e WPPT). Ocorre que é evidente que os referidos tratados não poderiam prever uma evolução tão acentuada das formas de uso de obras diversas (como musicais e de audiovisual) sob a forma digital.

Os tratados são de 1996 e, portanto, bastante anteriores ao streaming como hoje é conhecido, em suas mais variadas formas. 0 mais contemporâneo que os Tratados de Internet da OMPI conseguiu chegar ao conceito de streaming, pode-se arriscar dizer, foi o estabelecimento do denominado direito de colocação à disposição. Tal direito, de fato, indicava uma evolução no conceito de uso das obras pois previa a possibilidade de o usuário final ter acesso a obras e, inclusive, acedê-las e baixa-las em seu próprio equipamento. A discussão era muito mais voltada, naqueles idos, à possibilidade de se estar diante de uma reprodução, fosse temporária ou de caráter mais permanente.

No caso da lei brasileira as discussões inerentes ao streaming se referem basicamente à adequabilidade deste ser considerado uma modalidade de (ou, ao menos, exploração comercial 
ISSN 1981-3694

(DOI): $10.5902 / 1981369453336$

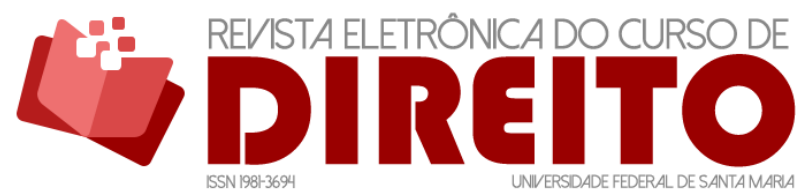

O STREAMING SOB UM OLHAR HERMENÊUTICO DO DIREITO DE

AUTOR

LARA SANTOS ZANGerolame TAROCO VICTOR GAMEIRO DRUMMOND

vinculada à) comunicação ao público (Art. 68 da Lei 9610/98 - LDA) ou à reprodução (Art. 29, I da mesma LDA). Obviamente que a transmissão como ato inerente a fluxo de dados e, numa evolução, de obras e interpretações, também releva, e exatamente por isso foi devidamente apresentada no início deste estudo.

Por outro lado, o direito de colocação à disposição figura no ordenamento brasileiro (como a sua adequabilidade ou não) como em outros ordenamentos nacionais e bem como no cenário internacional. Em extenso e produtivo parecer ${ }^{36}$ encaminhado ao STJ, o diretor da então DDI (Diretoria de Direitos Intelectuais do Ministério da Cultura), Marcos Alves de Souza, analisou todas as formas de utilização possíveis de obras suscetíveis a streaming. E, em suma, se posicionou-se a favor de que haja execução pública de obras inclusive no streaming interativo.

Seja pela forma de execução pública de obras musicais ou exibição audiovisual (espécies de comunicação ao público), colocação ou disposição outras aplicações técnico jurídicas, à toda a evidência a exploração de obras protegidas deve gerar uma remuneração aos titulares dos direitos, sobretudo, aos criadores, sobretudo pela sua fragilidade sistêmica.

Dentre as modalidades especificamente determinadas na lei nacional, o streaming relaciona-se muito mais com as atividades de comunicação ao público do que com a reprodução, visto que não se trata (na maior parte das vezes) de ato de reprodução dos arquivos em aparatos técnicos daquele que promove a reprodução, mas de sucessivos usos de arquivos digitais pelo usuário final. Ainda que fosse o caso, seria relevante também entender se estar-se-ia diante de uma nova forma de reprodução, pois se assim o fosse, a possibilidade de multiplicidade de acesso às obras, não se pode esquecer, é o fundamento da remuneração do sistema de direito de autor.

De toda forma, o direito de colocação à disposição se caracteriza por ser uma forma de exploração por meio da qual uma obra é disponibilizada para que o usuário possa a ele ter acesso em local e momento que seja de seu interesse, sem que haja a distribuição de exemplares. Neste sentido, e, em conclusão, o streaming é modalidade de exploração comercial não especificamente prevista na LDA que, por seu turno, apresenta relação próxima com o “direito de colocação à disposição" (making avaiable right) e ainda mais aproximada com o ato de comunicação ao público, não sendo, em nenhuma hipótese, considerado um ato de reprodução pura e simples.

Se fosse um ato de reprodução pura e simples, deveria gerar o pagamento aos titulares e,

\footnotetext{
${ }^{36}$ Nota técnica $026 \mathrm{DDI} / \mathrm{MinC}$ de 2016, enviada pelo ofício $039 \mathrm{DDI} / \mathrm{SE} / \mathrm{MinC}$ para o Ministro do STJ Ricardo Villas Bôas Cueba em referência ao Recurso Especial 1559264/RJ.
} 
ISSN 1981-3694

(DOI): $10.5902 / 1981369453336$

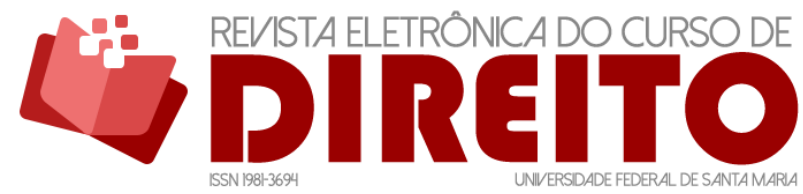

O STREAMING SOB UM OLHAR HERMENÊUTICO DO DIREITO DE

AUTOR

LARA SANTOS ZANGerolame TAROCO VICTOR GAMEIRO DRUMMOND

sobretudo, aos criadores das obras e interpretações utilizadas. Sendo considerado um direito vinculado ao ato de comunicação ao público, o mesmo se daria por outra modalidade de uso, o mesmo ocorrendo com a execução ou exibição pública.

O que releva, pois, para este breve estudo, é compreender a lógica sistêmica de atribuição de direitos e consequentemente remuneração, pelo de obras a todos os participantes de uma cadeia produtiva. Consultando o quadro 4 se observa as modalidades aplicáveis (em tese) para os atos de streaming, excluído destes o já indicado ato de transmissão definido e compreendido na parte inicial deste estudo:

Quadro 4. Direitos previstos na Lei $9.610 / 98$ que relevam para o estudo do streaming

\begin{tabular}{|c|c|}
\hline Direito aplicável & Texto legal \\
\hline Direito de comunicação ao público & $\begin{array}{l}\text { Art. } 5^{\circ} \text { Para os efeitos desta Lei, considera-se: } \\
\text { (...) } \\
\text { V - comunicação ao público - ato mediante o qual a } \\
\text { obra é colocada ao alcance do público, por qualquer } \\
\text { meio ou procedimento e que não consista na } \\
\text { distribuição de exemplares; }\end{array}$ \\
\hline $\begin{array}{l}\text { Modalidade de direito de distribuição por } \\
\text { meio de diversas opções de transmissão }\end{array}$ & $\begin{array}{l}\text { Art. 29. Depende de autorização prévia e expressa do } \\
\text { autor a utilização da obra, por quaisquer modalidades, } \\
\text { tais como: (...) VII - a distribuição para oferta de obras } \\
\text { ou produções mediante cabo, fibra ótica, satélite, } \\
\text { ondas ou qualquer outro sistema que permita ao } \\
\text { usuário realizar a seleção da obra ou produção para } \\
\text { percebê-la em um tempo e lugar previamente } \\
\text { determinados por quem formula a demanda, e nos } \\
\text { casos em que o acesso às obras ou produções se faça } \\
\text { por qualquer sistema que importe em pagamento pelo } \\
\text { usuário; }\end{array}$ \\
\hline $\begin{array}{l}\text { Direito de colocação à disposição } \\
\text { (exclusivo para titulares de direitos } \\
\text { conexos) }\end{array}$ & $\begin{array}{l}\text { Art. } 90 \text {. Tem o artista intérprete ou executante o } \\
\text { direito exclusivo de, a título oneroso ou gratuito, } \\
\text { autorizar ou proibir: (...) IV - a colocação à disposição } \\
\text { do público de suas interpretações ou execuções, de } \\
\text { maneira que qualquer pessoa a elas possa ter acesso, } \\
\text { no tempo e no lugar que individualmente escolherem; }\end{array}$ \\
\hline
\end{tabular}

Como se percebe, portanto, a modalidade de direito de colocação à disposição do público não foi apresentada no dispositivo que trata das definições (art. $5^{\circ}$ ). No mesmo sentido, também não foi apresentado na sua forma tecnicamente mais adequada como modalidade de direito patrimonial (art. 29) ainda que a possibilidade de distribuição para oferta por meio de diversas modalidades de transferências esteja prevista neste artigo.

Melhor dizendo, há a previsão de uma modalidade de distribuição (o que obviamente comporta um direito de natureza patrimonial) mas não exatamente um direito de colocação à disposição. Por fim, e de forma curiosa, a previsão de direito de colocação à disposição está 
ISSN 1981-3694

(DOI): $10.5902 / 1981369453336$

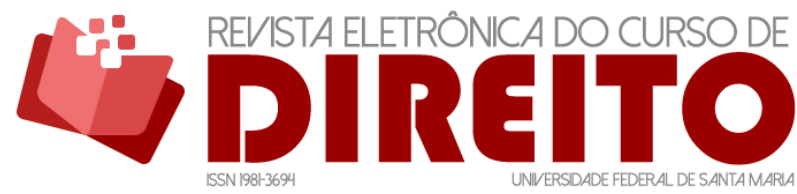

O STREAMING SOB UM OLHAR HERMENÊUTICO DO DIREITO DE

AUTOR

LARA SANTOS ZANGerolame TAROCO VICTOR GAMEIRO DRUMMOND

presente para os titulares de direitos conexos no art. 90 da Lei 9610/98. A interatividade, portanto, está prevista no referido art. 90.

Não obstante, no mínimo duas decisões bastante relevantes (ambas em grau de tribunais superiores citar os números dos casos), uma do STJ e outra do STF dão alguma luz às circunstâncias fáticas, relevando indicar que inclusive, foram decisões anteriormente submetidas à audiência pública (a do STJ na verdade, somente) o que possibilitou à Corte transitar em muitos argumentos favoráveis ou não à aplicação do streaming num importante caso brasileiro ${ }^{37}$.

Considerado o entorno da legislação aplicável, há de se compreender que o streaming não configura modalidade especificamente determinada na lei brasileira com absoluta exatidão. Pode haver uma série de fatores que justificam esta inexatidão, mas o histórico é, sem dúvida, o mais proeminente deles. A legislação em vigor sobre a matéria data de 1998, momento em que a tecnologia ainda engatinhava.

\section{A COMPREENSÃO DO ATO DE STREAMING À LUZ DA HERMENÊUTICA CONTEMPORÂNEA}

É precisamente neste ponto de inexatidão que a hermenêutica filosófica assume maior relevância. Nessa esteira, cumpre mencionar que Gadamer destaca a impossibilidade de abordar um ponto semântico zero, um marco zero de compreensão, justamente porque estamos inseridos em "um diálogo infinito que sempre se reinicia novamente e sempre emudece uma vez mais, sem jamais encontrar um fim"38 e esse processo se dá considerando que o sujeito está inserido em uma tradição.

A ideia do princípio da história efeitual coaduna-se simetricamente com esta proposta, pois ressalta a influência que a história possui para o ser humano, a ponto de moldar o compreender. Sendo assim, cada época entende um texto transmitido de "uma maneira peculiar, pois o texto constitui parte do conjunto de uma tradição pela qual cada época tem um interesse objetivo e na qual tenta compreender a si mesma”39.

Portanto, nesse viés hermenêutico, toda compreensão humana é dotada de uma

\footnotetext{
${ }^{37}$ BRASIL. Superior Tribunal de Justiça. Recurso Especial $n^{\circ}$ 1.559.264. Relator: Min. Ricardo Villas Bôas Cueva, 08 de fevereiro de 2017; BRASIL. Superior Tribunal de Justiça. Recurso Especial $n^{\circ}$ 1.567.780. Relator: Ministro Ricardo Villas Bôas Cueva, 14 de março de 2017b.

38 GADAMER, Hans-George. Hermenêutica em retrospectiva: a virada hermenêutica. 2. ed. Rio de Janeiro: Vozes, 2007. p. 182.

${ }^{39}$ GADAMER, Hans-George. Verdade e Método. 3. ed. Petrópolis: Editora Vozes, 1997. p. 366.
} 
ISSN 1981-3694

(DOI): $10.5902 / 1981369453336$

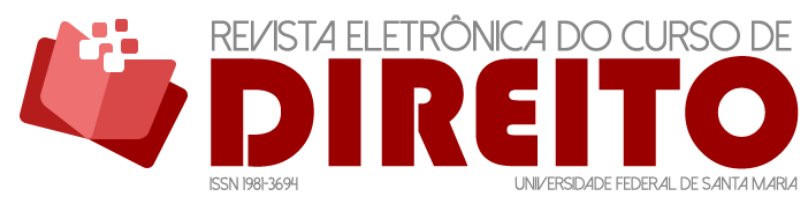

O STREAMING SOB UM OLHAR HERMENÊUTICO DO DIREITO DE

AUTOR

LARA SANTOS ZANGerolame TAROCO VICTOR GAMEIRO DRUMMOND

temporalidade, sendo fundamental compreender, no tempo, o que se entende por reprodução na história do direito do autor, por exemplo. Isso porque, o sentido está sempre determinado também pela situação histórica do intérprete e, por consequência, pela totalidade do processo histórico ${ }^{40}$ que influi na construção do direito do autor.

A própria linguagem cuida de evidenciar essa condição histórica, uma vez que "a linguagem é a grande instituição - a instituição das instituições - que sempre nos precedeu a todos" ${ }^{41}$. Por assim ser, somos seres falantes e dependentes, não somente do nosso sistema linguístico, mas também das coisas que já foram ditas, compreendidas e agregadas à própria língua ${ }^{42}$. Assim, é possível afirmar que “o mundo tal qual experimentamos é um mundo que se exprime em uma linguagem e por meio de uma identidade histórica"43, esta que não pode ser desprezada, pois é condição prévia de compreensão.

O Iluminismo, em sua cruzada contra os pré-juízos, sustentou o abandono desta construção em face da adoção da suposta objetividade trazida pela construção da razão, que se pauta na noção de que "só pode ser reconhecido como verdadeiro aquilo que foi fundado na razão com base em uma primeira certeza" ${ }^{44}$. Nesse passo, em uma visão dicotômica, o viés iluminista exclui os pré-juízos e desvaloriza qualquer conhecimento fundado na tradição e na autoridade $^{45}$, acusando essas compreensões de abrirem completamente as portas para um subjetivismo irrestrito, o qual aniquila qualquer possibilidade de construção legítima de entendimento.

A abordagem hermenêutica considera outros parâmetros e compreende que os pré-juízos não abririam completamente as portas ao subjetivismo, na medida em que se trata justamente de desenvolver antecipações que fossem adequadas à coisa a ser entendida, sendo a interpretação “um convite ao intérprete, para um exame crítico de seus pré-juízos”" Não se trata de algo puramente subjetivo, na medida em que os preconceitos são estruturas prévias de compreensão compartilhadas. Assim, a sua reabilitação dos preconceitos conduz, todavia, “à admoestação crítica de dar-se conta da própria preconceituosidade, para que o próprio texto se apresente em sua diversidade e chegue, assim, à possibilidade de jogar sua própria verdade

\footnotetext{
${ }^{40}$ SCHMIDT, Lawrence K. Hermenêutica. Rio de Janeiro: Editora Vozes, 2001. p. 134.

${ }^{41}$ GRONDIN, Jean. Hermenêutica. São Paulo: Parábola, 2012. p.107

42 ALMEIDA, Almiro Eduardo; RECK, Janriê Rodrigues. Direito e ação comunicativa: apresentação e fundamentação teórica da matriz linguístico-pragmática de Jünger Habermas e suas repercussões na compreensão do Direito. HS Editora: Porto Alegre, 2013. p.43.

${ }^{43}$ GRONDIN, Jean. Hermenêutica. São Paulo: Parábola, 2012. p. 108.

${ }^{44}$ GRONDIN, Jean. Hermenêutica. São Paulo: Parábola, 2012. p.69.

${ }^{45}$ SCHMIDT, Lawrence K. Hermenêutica. Rio de Janeiro: Editora Vozes, 2001. p. 147.

${ }^{46}$ SCHMIDT, Lawrence K. Hermenêutica. Rio de Janeiro: Editora Vozes, 2001. p. 146.
} 
ISSN 1981-3694

(DOI): $10.5902 / 1981369453336$

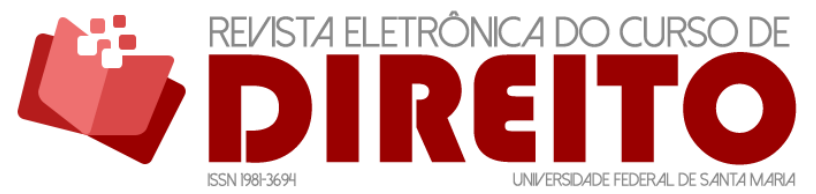

O STREAMING SOB UM OLHAR HERMENÊUTICO DO DIREITO DE

AUTOR

LARA SANTOS ZANGerolame TAROCO VICTOR GAMEIRO DRUMMOND

objetiva contra a própria pré-concepção". ${ }^{47}$

$\mathrm{Na}$ esteira desse pensamento, é possível asseverar que o intérprete do Direito, ao acessar o texto jurídico, o faz já munido de certas construções de sentido, de pré-compreensões, não meros subjetivismos, mas condição de toda compreensão ${ }^{48}$. Desse modo, o intérprete ao interagir o texto normativo com o caso concreto, em uma verdadeira fusão de horizontes, não volta da mesma maneira desta fusão, em razão do exame crítico pode reformular seus préconceitos originais, modificando-os ou consolidando-os, construindo novos espaços de compreensão.

Gadamer aponta como círculo hermenêutico o que ocorre no momento em que o sujeito, por intermédio de sua pré-compreensão, insere-se na construção de sentido do objeto e, ao mesmo tempo, o objeto no decorrer do processo hermenêutico, modifica a compreensão do intérprete ${ }^{49}$. Como se vê, a compreensão não se trata de mera reprodução do sentido do texto original, trata-se de um processo muito mais complexo, com intenso envolvimento do intérprete.

Essa constatação evidencia a debilidade, do ainda persistente, modelo jurídico que ambiciona subsumir o fato à norma, excluindo qualquer possibilidade de inserção do intérprete e das pré-compreensões que acompanham seu entendimento durante a aplicação, que para essa percepção além de ser um momento separado da compreensão e da interpretação, também é meramente automático e longe da inclusão do intérprete.

Essa pretensão se enquadra numa tradição jurídica positivista, cuja pretensão metodológica é assumir um descritivismo de cunho adequacionista, isto é, adotando proposições descritivas para negar qualquer tipo de metafísica, tratando a verdade como uma adequação do intelecto ao objeto ${ }^{50}$. Em Kelsen, no contexto do positivismo normativista, a interpretação é tida como "uma operação mental que acompanha o processo da aplicação do Direito no seu progredir de um escalão superior para um escalão inferior"51. Nesse processo o que o sujeito que interpreta o Direito faz é "deduzir da norma geral da lei na sua aplicação a um caso concreto" 52 .

O direito ao pretender regular a questão do streaming, buscando sua eventual correspondência com previsões legais já existentes, não deve operar a partir dessa racionalidade adequacionista. Mas, considerando o giro-linguístico da hermenêutica filosófica deve considerar

\footnotetext{
${ }^{47}$ GRONDIN, Jean. Introdução à hermenêutica filosófica. São Leopoldo: UNISINOS, 1999. p. 129.

48 STRECK, Lenio. Hermenêutica jurídica $\mathbf{e}(\mathrm{m})$ crise: uma exploração hermenêutica. 10. ed. Porto Alegre: Livraria do Advogado, 2011. p. 247.

49 STRECK, Lenio Luiz. Verdade e consenso: constituição, hermenêutica e teorias discursivas. 4.ed. São Paulo: Saraiva, 2012. p.135.

${ }^{50}$ WARAT, Luís Alberto. Sobre la dogmática jurídica. Revista Sequência. Ano I, 1980.

51 KELSEN, Hans. Teoria Pura do Direito. 8.ed. São Paulo: Martins Fontes, 2005. p.387.

52 KELSEN, Hans. Teoria Pura do Direito. 8.ed. São Paulo: Martins Fontes, 2005. p.387.
} 
ISSN 1981-3694

(DOI): $10.5902 / 1981369453336$

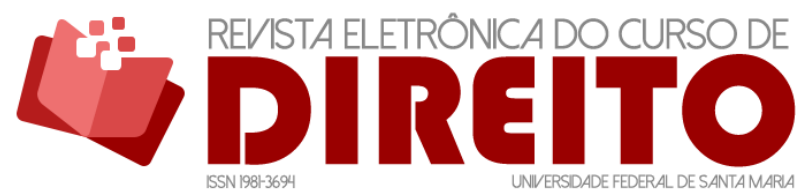

O STREAMING SOB UM OLHAR HERMENÊUTICO DO DIREITO DE

AUTOR

LARA SANTOS ZANGerolame TAROCO VICTOR GAMEIRO DRUMMOND

a historicidade e a facticidade que acompanham a evolução histórica do direito do autor, bem como seu embasamento filosófico, que opera enquanto telos ao nortear o ato interpretativo, cuja tarefa primordial, considerando as previsões do texto constitucional, é considerar o sujeitocriador.

Desconsiderá-lo e descolar essa análise do processo de construção de sentido é promover um esvaziamento semântico-estrutural ${ }^{53}$ desse direito. Feito isso, institui-se um verdadeiro paradoxo, na medida em que "o direito de autor sem autor e sem a compreensão de que esse é seu sujeito primordial é um não-direito de autor" ${ }^{\text {54 }}$.

0 que se identifica aqui, ao invés de um novo-conceito-jurídico-a-sair-do-zero, é um continuum tecnológico jurídico, enquanto circunstância histórica. Há que se reconhecer que não houve o desenvolvimento tecnológico de novos aparatos, ferramentas ou instrumentos de tecnologia, desde o surgimento da imprensa até o final do século XIX, que implicasse numa aplicação dos conceitos jurídicos que pudessem influenciar o sistema de direito de autor.

Não se pode deixar de considerar que, até o século XIX, a única possibilidade de multiplicação de exemplares ocorria, portanto, por meio da impressão, o que significa dizer que a centralidade da exploração das obras operava a partir do direito de reprodução. 0 ato de reprodução abarcava todos os direitos possíveis. Assim sendo, qualquer exploração comercial de uma obra se constitui - como uma consequência histórico-filosófica - como uma derivação da reprodução e, portanto, precisa ser compreendida não a partir de um grau zero de sentido, $a b$ ovo, mas sim considerando sua historicidade e facticidade tal qual propõe a hermenêutica filosófica a partir do giro linguístico.

No atual contexto de desenvolvimento da teoria do direito e considerando os aportes filosóficos ofertados pela hermenêutica filosófica, não cabe e nem se justifica retornar a abordagens quase exegéticas e dedutivistas para reduzir a complexidade da aplicação do direito a apropriações reducionista de termos como "reprodução". O sentido do texto jurídico não é uma mera objetiva subsunção lógica, como pretende certa compreensão que se recusa a reconhecer os direitos decorrentes do streaming, por este não se adequar ao conceito de reprodução enquanto categoria jurídica, a ser compreendida, por essa acepção, de forma estática, não suscetível as atualizações e ressignificações da linguagem enquanto construção

53 DRUMMOND, Victor Gameiro. The creative circle: why the linguistic turn is of philosophical interest in copyright law. Revista de Estudos Constitucionais, Hermenêutica e Teoria do Direito (RECHTD). v.5, n.1, 2013, p.78.

${ }^{54}$ DRUMMOND, Victor Gameiro. 0 déficit filosófico do direito de autor. Revista Paradigma. Ribeirão Preto. v.26, n.1, jan/jun, 2017, p.168. Disponível em: https://revistas.unaerp.br/paradigma/article/view/847/pdf. Acesso em: 06 de mai. 2020. p.187. 
ISSN 1981-3694

(DOI): $10.5902 / 1981369453336$

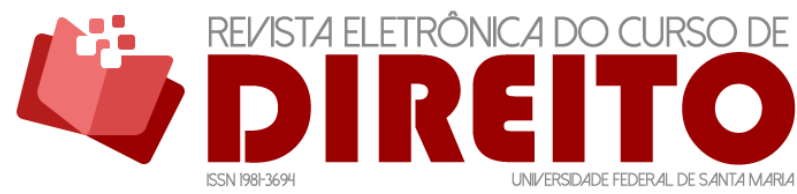

O STREAMING SOB UM OLHAR HERMENÊUTICO DO DIREITO DE

AUTOR

intersubjetiva.

O sentido do texto jurídico, considerando as contribuições hermenêuticas, está muito mais próximo a um construído ${ }^{55}$, que conta com intensa participação de quem constrói e, também, reflete a própria situação hermenêutica de quem interpreta, na medida em que "o mensageiro já vem com a mensagem", ou ainda "no conto está o contador"56. Nessa concepção, o sentido do texto é algo novo, haja vista que não é unicamente o resultado da soma das précompreensões do intérprete, mas também não é só texto.

Como consequência, mesmo que se considere que o tema necessita de maior maturação no ordenamento, também é verdade que o Estado da Arte deve ser analisado sob o viés de uma compreensão do direito de autor do ponto de vista de toda a sua sistemática e filosofia aplicável. Essa, estruturada a partir de uma abordagem hermenêutica, a qual transcende um pensar que se restringe a critérios lógico-descritivos deve apoiar-se na justificação filosófica do direito autor, cuja coerência interna demanda a centralidade do sujeito-criador, enquanto parâmetro de compreensão a guiar, inclusive, a adequação das novas tecnologias.

E se o sistema pretende, verdadeiramente, promover a defesa do sujeito-criador, ele deverá fazê-lo considerando que os direitos necessitam ser observados à luz de uma hermenêutica que compreende a remuneração do criador como consequência da multiplicação de acesso às suas criações. Novas modalidades de uso não precisam ser indicadas como tais para gerar uma obrigatoriedade de respeito aos direitos. Basta conhecer o sistema. Se o sistema tem, realmente, como objetivo atribuir direitos e remunerar os criadores, o que menos importa é o nome, no Direito, que se dará as circunstâncias fáticas que derivam - insistimos, histórica e filosoficamente - da reprodução, o ato primordial de multiplicação de acesso às criações.

É, afinal, o que pretende este estudo, pavimentar este terreno com as ferramentas que a hermenêutica apresenta.

\section{CONCLUSÃO}

Em 1962, John Austin publicou “Como fazer coisas com palavras”, que reúne doze conferências proferidas pelo autor em 1955, na Universidade de Harvard. Dentre as tantas contribuições de Austin, a que guarda pertinência com este estudo é a constatação de que a

55 STRECK, Lenio Luiz. 0 direito como um conceito interpretativo. Revista Pensar. Fortaleza, v.15, n.2, jul/dez, 2010, p.506.

${ }_{56}$ STRECK, Lenio. Jurisdição Constitucional e Hermenêutica. 2. ed. Rio de Janeiro: Forense, 2004, p. 198. 
ISSN 1981-3694

(DOI): $10.5902 / 1981369453336$

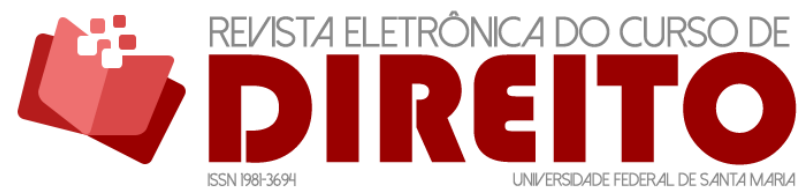

O STREAMING SOB UM OLHAR HERMENÊUTICO DO DIREITO DE

AUTOR

LARA SANTOS ZANGerolame TAROCO VICTOR GAMEIRO DRUMMOND

linguagem não é apenas utilizada para transmitir informações, mas também para praticar ações. Dito de outro modo, para Austin, dizer é também fazer, pois pela linguagem se afeta e interfere no comportamento do interlocutor ${ }^{57}$.

A virada pragmática na linguística moderna ${ }^{58}$, a qual se filia Austin, é responsável por ir além da investigação semântica e considerar não só o significado de dada sentença. Nessa acepção, a linguagem não tem apenas uma função constatativa, responsável por descrever objetivamente o mundo, mas é também uma ação intencional. Tanto por isso, todo dizer é, em alguma medida, um fazer, ao passo que, pelos atos de fala, são realizadas ações semânticas, dado que, pela enunciação linguística, quem fala expressa conscientemente dada significação e, em virtude da função performática da linguagem, também realiza algo.

Não restam dúvidas que no Direito, mergulhado e constituído pela/em linguagem, os juristas também fazem coisas com palavras. E, como se pretendeu desmontar com este estudo, bem compreendê-las, considerando sua inserção histórico-filosófica, é condição de possibilidade para se estabelecer uma interpretação coerente, principalmente quando se trata do direito de autor. O caráter constitutivo de direitos, deveres e relações jurídicas confere ainda mais responsabilidade ao lidador do Direito, dada a potência que interpretações inadequadas tendem a assumir.

Ao explorara o streaming sob um olhar hermenêutico do direito de autor se pretendeu ressaltar justamente as repercussões jurídicas de uma inadequada forma de fazer as coisas com palavras. Isto é, utilizando-as de forma restritiva para negar direitos aqueles que deveriam ser os principais sujeitos da proteção conferida por esse ramo do Direito. Embora o streaming tenha ares contemporâneos, uma vez que criado em 2016, o que se verifica a partir de uma análise hermenêutica, é que sob o véu de uma nova tecnologia está um continuum tecnológico jurídico, enquanto circunstância histórica.

Isso porque, e como já adiantado, como não houve o desenvolvimento tecnológico de novos aparatos e etc. desde o século XV até o século XIX, a multiplicação de exemplares se dava somente por meio da impressão, o que repercute na centralidade do direito de reprodução, na medida em que o ato de reprodução abarcava todos os direitos possíveis. Por isso, qualquer exploração comercial de uma obra se constitui - como uma consequência histórico-filosófica como uma derivação da reprodução e, portanto, não deve ser compreendida a partir de um grau

\footnotetext{
${ }^{57}$ AUSTIN, John L. How to do things with words. Oxford: Clarendon, 1962. p.25.

58 ALMEIDA, Almiro Eduardo; RECK, Janriê Rodrigues. Direito e ação comunicativa: apresentação e fundamentação teórica da matriz linguístico-pragmática de Jünger Habermas e suas repercussões na compreensão do Direito. HS Editora: Porto Alegre, 2013. p.45.
} 
ISSN 1981-3694

(DOI): $10.5902 / 1981369453336$

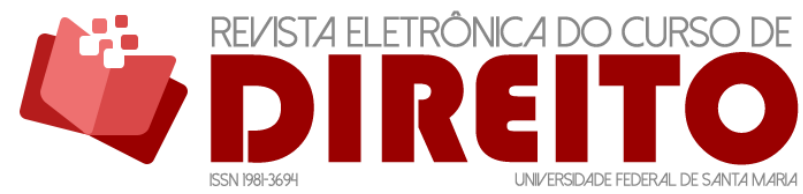

O STREAMING SOB UM OLHAR HERMENÊUTICO DO DIREITO DE

AUTOR

LARA SANTOS ZANGerolame TAROCO VICTOR GAMEIRO DRUMMOND

zero de sentido.

Ao considerar os aportes ofertados pela hermenêutica filosófica, não se pode pretender regular juridicamente o streaming buscando uma mera correspondência literal e adequacionista com as previsões já existentes. Esse intento nasce falho por uma óbvia questão temporal, tendo em vista que as legislações de direito do autor, bem como a Constituição, são anteriores à criação do próprio streaming. Isso significa que o direito então não fornece meios para tratar dessa questão? Com base no que foi apresentado por este estudo, a resposta é negativa. A partir do giro-linguístico da hermenêutica filosófica, a historicidade e a facticidade que acompanham a evolução histórica do direito do autor são consideradas para nortear o ato interpretativo, assegurando a centralidade do sujeito-criador.

Desconsiderá-lo e descolar essa análise do processo de construção de sentido é promover um esvaziamento semântico-estrutural ${ }^{59}$ desse direito. Dado que o sentido do texto jurídico não é uma mera objetiva subsunção lógica, há que se interpretar a reprodução considerando justamente esse telos protetivo previsto no texto constitucional e que também justifica o próprio direito do autor. Ao pensar as categorias jurídicas de direito do autor nesse viés garantese a coerência interna e a integridade do próprio Direito, que prontamente adapta-se às mudanças temporais e tecnológicas, pois é também constituído pela linguagem, cuja principal característica é a contínua construção e reconstrução intersubjetiva.

Essa pré-compreensão passa à condição de possibilidade nesse novo modo de olhar a hermenêutica jurídica, como afirma Streck, o que não significa dizer que isso depende da discricionariedade do interprete, porque esse sujeito que interpreta está inserido em uma tradição e é também constrangido por ela. Portanto, “os sentidos que atribuirá ao texto não dependem de sua vontade, por mais que assim queiram os adeptos do esquema sujeitoobjeto" 60 . O processo unitário da compreensão, pelo qual interpretar é também aplicar, desmitifica então a tese de que primeiro se conhece algo para somente depois interpretá-lo e aplica-lo, promovendo um repensar do Direito, tantas vezes impregnado por formas insuficientes que seguem reproduzindo paradigmas filosóficos já superados, usados para negar direitos aos sujeitos-criadores.

59 DRUMMOND, Victor Gameiro. The creative circle: why the linguistic turn is of philosophical interest in copyright law. Revista de Estudos Constitucionais, Hermenêutica e Teoria do Direito (RECHTD). v.5, n.1, 2013, p.78.

60 STRECK, Lenio Luiz. De como o positivismo jurídico tomou o caminho da ontoteologia. STRECK, Lenio Luiz; CULLETON, Alfredo; REIS, Róbson Ramos dos. (Org.). Festschrift: um tributo a Ernildo Stein - viveu às voltas com a metafísica e a fenomenologia. São Leopoldo: Unisinos, 2015. p. 105 
ISSN 1981-3694

(DOI): $10.5902 / 1981369453336$

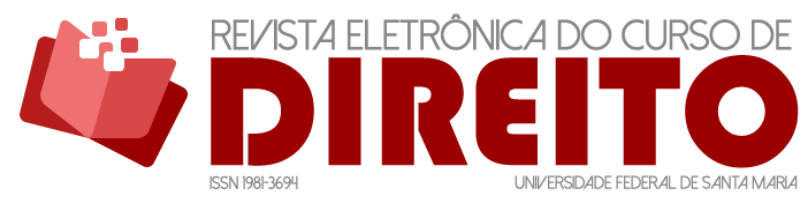

O STREAMING SOB UM OLHAR HERMENÊUTICO DO DIREITO DE

AUTOR

LARA SANTOS ZANGEROLAME TAROCO VICTOR GAMEIRO DRUMMOND

\section{REFERÊNCIAS}

ALMEIDA, Almiro Eduardo; RECK, Janriê Rodrigues. Direito e ação comunicativa: apresentação e fundamentação teórica da matriz linguístico-pragmática de Jünger Habermas e suas repercussões na compreensão do Direito. HS Editora: Porto Alegre, 2013.

AUSTIN, John L. How to do things with words. Oxford: Clarendon, 1962.

BRASIL. Constituição da República Federativa do Brasil de 1998. Presidência da República. Disponível em: http://www.planalto.gov.br/ccivil_03/constituicao/constituicao.htm. Acesso em: 09 jul. 2020.

BRASIL. Lei $n^{\circ}$ 9.610, de 19 de fevereiro de 1998. Altera, atualiza e consolida a legislação sobre direitos autorais e dá outras providências. Presidência da República. Disponível em:

http://www.planalto.gov.br/ccivil_03/leis/l9610.htm. Acesso em: 09 jul. 2020.

BRASIL. Superior Tribunal de Justiça. Recurso Especial $n^{\circ}$ 1.559.264. Relator: Min. Ricardo Villas Bôas Cueva, 08 de fevereiro de 2017. Disponível em:

https: / /scon.stj.jus.br/SCON/jurisprudencia/toc.jsp?livre=1559264\&b=ACOR\&thesaurus=JURIDIC O\&p=true. Acesso em: 09 jul. 2020.

BRASIL. Superior Tribunal de Justiça. Recurso Especial $n^{\circ}$ 1.567.780. Relator: Min. Ricardo Villas Bôas Cueva, 14 de março de 2017b. Disponível em:

https: //scon.stj.jus.br/SCON/jurisprudencia/toc.jsp?livre=1567780\&b=ACOR\&thesaurus=JURIDIC O\&p=true Acesso em: 09 jul. 2020.

DRUMMOND, Victor. 0 ator e o não-direito do criador inominado. In: MOREIRA, Nelson Camatta;

DE PAULA, Rodrigo Francisco de (org.). Direito e literatura distópica. São Paulo: Tirant Lo Blanch, 2020.

DRUMMOND, Victor Gameiro. The creative circle: why the linguistic turn is of philosophical interest in copyright law. Revista de Estudos Constitucionais, Hermenêutica e Teoria do Direito (RECHTD). v.5, n.1, 2013.

DRUMMOND, Victor Gameiro. O déficit filosófico do direito de autor. Revista Paradigma. Ribeirão Preto. v.26, n.1, jan/jun, 2017.

DRUMMOND, Victor Gameiro. Baena e Dias: pioneiros dos privilégios atribuídos aos autores portugueses no século XVI e suas consequências nas novas tecnologias. Revista Brasileira de Direito. Passo Fundo, v. 13, n.3, 2017.

EVENS, T.; DONDERS, K. Platform Power and Policy in Transforming Television Markets.

Palgrave Macmillan, 2018, p.4. Disponível em:

https://www.degruyter.com/document/doi/10.1515/commun-2019-2034/html.

Acesso em: 10 jun. 2021.

GADAMER, Hans-George. Verdade e Método. 3. ed. Petrópolis: Editora Vozes, 1997.

GADAMER, Hans-George. Hermenêutica em retrospectiva: a virada hermenêutica. 2. ed. Rio de Janeiro: Vozes, 2007. 
GRONDIN, Jean. Introdução à hermenêutica filosófica. São Leopoldo: UNISINOS, 1999.

GRONDIN, Jean. Hermenêutica. São Paulo: Parábola, 2012.

HAMPTON-SOSA, William. The Access Model for Music and the Effect of Modification, Trial, and Sharing Usage Rights on Streaming Adoption and Piracy. Journal of Theoretical and Applied Electronic Commerce Research. Talca, v.14, n.3, set, 2019. Disponível em: https://www.mdpi.com/0718-1876/14/3/25.Acesso em: 10 jun. 2021.

HORNER, Stephanie N. DMCA: Professional Sports Leagues' Answer to Protecting Their Broadcasting Rights against Illegal Streaming. Marquette Sports Law Review, v.24, n.6, 2014. Disponível em: https: / / heinonline.org/HOL/LandingPage?handle=hein.journals/mqslr24\&div=19\&id=\&page=. Acesso em: 13 jun. 2021.

HUTCHINS, Brett; LI, Bo. ROWE, David. Over-the-top sport: live streaming services, changing coverage rights markets and the growth of media sport portals. Media, Culture \& Society, v.41, n.7, 2019. Disponível em: https://journals.sagepub.com/doi/pdf/10.1177/0163443719857623. Acesso em: 11 jun. 2021.

KELSEN, Hans. Teoria Pura do Direito. 8.ed. São Paulo: Martins Fontes, 2005.

KISCHINHEVSKY, Marcelo. Em busca da música infinita: os serviços de streaming e os conflitos de interesse no mercado de conteúdos digitais. São Leopoldo: Unisinos, 2015.

LIN, Carolyn A. Technology fluidity and on-demand webcasting adoption. Telematics and Informatics. v. 12, n.2, mai. 2008.

MÉXICO. Ley Federal del Derecho de Autor. Nueva Ley publicada en el Diario Oficial de la Federación el 24 de diciembre de 1996. Disponível em: http://www.diputados.gob.mx/LeyesBiblio/pdf/122_010720.pdf. Acesso em: 10 jun. 2021.

ROSATI, Eleonora. Does the Duration of the Storage Matter? Live Streaming Providers As 'Online Content Sharing Service Providers' Under Directive 2019/790. European Intellectual Property Review, 2020.

ROSE, Mark. Authors and Owners: The invention of copyright, Harvard University Press, London: 1993.

SAKTHIVEL, Marc. Evolution of the Authors' Right of Communication to Public: Implications to Broadcasters in the Context of Live Streaming. In: SAKTHIVEL, Marc. Broadcasters' Rights in the Digital Era: copyright concerns on live streaming. Leiden: Brill\&Nijhoff, 2020.

SCHMIDT, Lawrence K. Hermenêutica. Rio de Janeiro: Editora Vozes, 2001.

STRECK, Lenio Luiz. Jurisdição Constitucional e Hermenêutica. 2. ed. Rio de Janeiro: Forense, 2004.

STRECK, Lenio Luiz. O direito como um conceito interpretativo. Revista Pensar. Fortaleza, v.15, n.2, jul/dez, 2010.

STRECK, Lenio Luiz. Hermenêutica jurídica e(m) crise: uma exploração hermenêutica. 10. ed. Porto Alegre: Livraria do Advogado, 2011. 
STRECK, Lenio Luiz. Verdade e consenso: constituição, hermenêutica e teorias discursivas. 4.ed. São Paulo: Saraiva, 2012.

STRECK, Lenio Luiz. De como o positivismo jurídico tomou o caminho da ontoteologia. In: STRECK, Lenio Luiz; CULLETON, Alfredo; REIS, Róbson Ramos dos. (Org.). Festschrift: um tributo a Ernildo Stein - viveu às voltas com a metafísica e a fenomenologia. São Leopoldo: Unisinos, 2015.

STRECK, Lenio Luiz. Dicionário de hermenêutica: quarenta temas fundamentais da Teoria do Direito à luz da Crítica Hermenêutica do Direito. Belo Horizonte: Letramento, 2017.

WOLKMER, A. C.; LEITE, J. R. N (Org). Os "novos" direitos no Brasil: natureza e perspectivas uma visão básica das novas conflituosidades jurídicas. 3. ed. São Paulo: Saraiva, 2016

WACHOWICZ, Marcos. A gestão coletiva de direitos autorais da obra musical:titularidade originária, supervisão pública e transparência. In: SIMÃO, J.F.; BELTRÃO, S.R. Estudos em Homenagem a José de Oliveira Ascensão - Direito Civil: Estudos Em Homenagem A José De Oliveira Ascensão: Direito Privado. Editora: Atlas, 2015.

WACHOWICZ, Marcos. O "novo" direito autoral na sociedade informacional. In: WOLKMER, A. C.; LEITE, J. R. N (Org). Os "novos" direitos no Brasil: natureza e perspectivas - uma visão básica das novas conflituosidades jurídicas. 3. ed. São Paulo: Saraiva, 2016.

WARAT, Luís Alberto. Sobre la dogmática jurídica. Revista Sequência. Santa Catarina, v.02, n. 02, 1981. Disponível em: https://periodicos.ufsc.br/index.php/sequencia/article/view/17261. Acesso em: 09 jul. 2020.

Recebido em: 14.11.2020 / Revisões requeridas em: 01.06.2021 / Aprovado em: 12.08.2021 / Publicado em: 30.11.2021

\section{COMO FAZER REFERÊNCIA AO ARTIGO (ABNT):}

DRUMMOND, Victor; TAROCO, Lara. O streaming sob um olhar hermenêutico do direito do autor. Revista Eletrônica do Curso de Direito da UFSM, Santa Maria, RS, v. 16, n. 2, e53336, maio/ago. 2021. ISSN 19813694. DOI: http://dx.doi.org/10.5902/1981369453336. Disponível em:

https://periodicos.ufsm.br/revistadireito/article/view/53336 Acesso em: dia mês. ano.

Direitos autorais 2021 Revista Eletrônica do Curso de Direito da UFSM

Editores responsáveis: Rafael Santos de Oliveira e Angela Araujo da Silveira Espindola

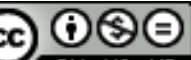

Esta obra está licenciada com uma Licença Creative Commons Atribuição-NãoComercial-SemDerivações 4.0 Internacional.

\section{SOBRE OS AUTORES}

LARA SANTOS ZANGEROLAME TAROCO

Doutoranda em Direito Público pela Universidade do Vale do Rio dos Sinos - UNISINOS (bolsista Capes/PROEX). Mestre em Direito pela Faculdade de Direito de Vitória - FDV. Secretaria executiva da Rede Brasileira Direito e Literatura - RDL. Advogada.

VICTOR GAMEIRO DRUMMOND

Pós-doutor em Direito pela Universidade de Lisboa. Doutor em Direito pela Universidade Estácio de Sá. Professor permanente do Mestrado em Direito da UniFG. Professor convidado da Universidade de Lisboa, Universidade Complutense de Madrid, Universidade de Santigo de Compostela e Universidade de Málaga. Presidente executivo da Interartis Brasil. Presidente do Instituto Latino de Direito e Cultura. Advogado. 